Evidence Paper 4

Wealth Tax Commission

Ways of taxing

wealth:

alternatives and interactions

Author

Andy Summers

N SCHOOL OF ECONOMICS AND political sCience

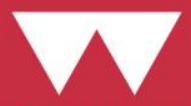

WARWICK 


\section{WAYS OF TAXING WEALTH: ALTERNATIVES AND INTERACTIONS}

Andy Summers, London School of Economics

Wealth Tax Commission Evidence Paper no. 4

Published by the Wealth Tax Commission

www.ukwealth.tax 


\section{Acknowledgements}

With thanks to Helen Hughson for her outstanding assistance with Appendix A, and to Arun Advani, David Burgherr, Emma Chamberlain, Nick O'Donovan, Carl Emmerson and Alan McGuiness for very helpful comments. Any errors remain my own.

The Wealth Tax Commission acknowledges funding from the Economic and Social Research Council (ESRC) through the CAGE at Warwick (ES/L011719/1) and a COVID-19 Rapid Response Grant (ES/V012657/1), and a grant from Atlantic Fellows for Social and Economic Equity's COVID-19 Rapid Response Fund. 


\section{Introduction}

This paper considers an important objection to a wealth tax: why introduce a new tax when government could just reform existing taxes on wealth?

On any view, the UK's current approach to taxing wealth is a mess. It lacks a clear set of objectives. The legislation is complex; anti-avoidance rules have often been used to patch systemic incoherence. There are large distortions, especially across different asset classes, for no good reason. Existing taxes - most of all inheritance tax - are unpopular, partly driven by a perception (which has some basis in reality) that the wealthiest do not pay.

There have been numerous prior recommendations for reform. The most wide-ranging are those contained in the Mirrlees Review, published in 2011, which proposed significant reforms to existing taxes on wealth as part of a review into the entire tax system. But a range of institutions have made recent recommendations on specific taxes. Each of these proposals differ somewhat in their details, and to some extent their objectives - but there is also a large measure of agreement between them.

Despite these recommendations, minimal progress has been made. There have been some positive developments: for example, an increase in dividend rates in 2016, and measures to limit Business Asset Disposal Relief (previously known as 'Entrepreneurs' Relief') for capital gains tax. But in the period since the Financial Crisis, there have been hardly any structural changes, and for some taxes, one must look much further back for the last major reform. ${ }^{1}$ More active areas of legislation, such as capital gains tax, have been characterised by as many steps backwards as forwards.

Given the flaws in the UK's existing approach to taxing wealth, could a new broad-based tax on the ownership of wealth - a 'wealth tax' - provide the solution? Two key issues must be considered here. First, to what extent (if at all) is a wealth tax really an alternative to reforming existing taxes? Second, if a new wealth tax was introduced, how should it interact with the other taxes in our current system? In this paper I provide a framework for answering both of these questions.

The next section (Section 2) outlines existing taxes on wealth, their main deficiencies, and options for reform. The aim is to synthesise existing proposals, not to develop new ones. I situate these proposals in the context of broader objectives for reform and highlight policies that are merited whichever broader view is taken. Space precludes a detailed evaluation of specific proposals, so I point to additional resources and restrict myself to mapping out the main options.

Section 3 considers whether a wealth tax could be justified in addition to or instead of reforms to existing taxes on wealth. I address two questions. First, if the reforms canvassed in Section 2 were implemented in full, would there be any role left for a wealth tax to play? Second, could a wealth tax provide an alternative to any of these reforms? My discussion on these issues draws extensively on Adam \& Miller (2020) and mirrors their key conclusions, though with some differences in emphasis.

The final section (Section 4) considers how a wealth tax should interact with existing taxes on wealth. Three questions arise. First, if a wealth tax were introduced, could any existing taxes be abolished? Second, should a wealth tax be deductible against other taxes? And third, could a wealth tax serve as a backstop for other taxes, in the form of an 'alternative minimum tax'? My aim here is again to map the main issues, rather than to provide an account of the technical details, which must depend on the precise form that a wealth tax takes.

\footnotetext{
${ }^{1}$ For example, the introduction of inheritance tax replacing capital transfer tax in 1986 (excepting the major changes to taxation of trusts in 2006), and the introduction of council tax in 1991.
} 


\section{Existing taxes on wealth}

This section reviews options for reforming the UK's existing taxes on wealth. This raises an immediate question: what counts as a 'tax on wealth'? If we mean personal taxes that have wealth as the tax base, the UK currently has no taxes of this type. But taxes are ultimately always 'on' people, albeit assessed by reference to something else: such as income, expenditure, transaction value etc. So, when commentators talk about how the UK taxes wealth, they may have in mind various taxes that affect people who own substantial wealth (or 'the wealthy'). ${ }^{2}$ This understanding leads us to an expansive definition of taxes on wealth, since the wealthy tend be affected by most taxes, to a greater or lesser extent.

At the core of the definition are the classic 'capital taxes': capital gains tax (CGT); inheritance tax (IHT) and stamp duty land tax (SDLT). ${ }^{3}$ To this can be added income tax on savings and investment income, on the basis that - like CGT - it taxes the returns that flow from having wealth. Beyond this, the choice of taxes to include in the definition is more contestable. Value added tax (VAT) could be thought of as a tax on (some forms of) expenditure out of accumulated wealth. Corporation tax reduces the effective return on wealth held in the form of shares. Council tax could be reformed to tax the ownership of wealth held in residential property, and the annual tax on enveloped dwellings (ATED) already does this in limited circumstances. All of these taxes potentially affect those with wealth, to varying degrees.

Consequently, to avoid excluding reforms that people might plausibly consider as alternatives to introducing a wealth tax, I adopt this broad notion of 'taxes on wealth' for the purposes of this paper. This involves looking beyond the core 'capital taxes' to recognise the multitude of other ways in which the tax system can affect people who own substantial wealth. There are four main ways in which the UK tax system could be said to tax the wealthy already: ${ }^{4}$

(1) Income tax and CGT tax the returns to wealth. Corporation tax also affects returns received by shareholders.

(2) IHT and SDLT tax transfers of wealth (although with SDLT there is typically no net transfer, merely an exchange).

(3) ATED taxes the ownership of wealth held in residential property, where the property is owned by a company and certain other conditions are satisfied. Owner-occupiers of residential property are liable to council tax.

(4) VAT taxes some of the ways in which wealth may be spent.

It is immediately evident from this list that the ways in which the UK already taxes the wealthy are piecemeal. The overall extent to which a wealthy individual is affected by the suite of existing taxes on wealth depends on several factors, including: the forms in which they hold their wealth, the extent of the financial returns (income and gains) that they receive from it, and the ways in which they spend or otherwise choose to use their wealth, for example by making gifts or bequests. Under our current system, there is no direct relationship between the amount of wealth that an individual owns and the amount of tax that they pay. In Section 3, I consider whether there

\footnotetext{
${ }^{2}$ The amount of wealth required to be considered 'wealthy' is of course highly contested and I will not attempt to specify a threshold. For a recent qualitative study of lay perceptions on this issue, based on focus groups held in London, see Davis et al. (2020).

${ }^{3}$ These taxes formed the focus of the chapter on 'taxation of wealth and wealth transfers' for the Mirrlees Review (Boadway, Chamberlain \& Emmerson, 2010).

${ }^{4}$ This approach reflects the tripartite scheme adopted in Hills et al. (2013), but with the addition of taxes on spending wealth. 
should be such a link. Before doing so, it is necessary to explain the UK's existing taxes on wealth in more depth.

\subsection{Overview and criticisms}

As background to discussion of options for reforming existing taxes on wealth, I start here with a short overview of each tax and the main criticisms that have been made of it. Readers already familiar with the UK tax system may skip this part. More detailed surveys are provided by Boadway, Chamberlain \& Emmerson (2010) and Summers (2019).

\subsubsection{Taxes on returns on wealth}

Income tax applies to income from owning shares (dividends), property (rent), savings (interest) and other investments. The income tax rate for most forms of savings and investment income is the same as for earnings from work (currently $20 \%, 40 \%$ or $45 \%$ depending on the taxpayer's marginal rate). Unlike earnings, there are no national insurance contributions (NICs), regardless of the taxpayer's age. Dividend income is charged at lower headline rates (currently $7.5 \%, 32.5 \%$ or $38.1 \%$ ) and benefits from an additional tax-free allowance, currently set at $£ 2000$ per year, although corporation tax is also paid on corporate profits prior to distribution. There is no income tax in respect of assets that do not yield any financial income-stream, even if they provide other benefits to the owner.

Four main criticisms can be made of this approach to taxing income from wealth. First, investment income is taxed at lower effective rates than earnings, mainly due to the wedge created by NICs; this distorts people's choices about how they work (Adam \& Miller, 2019) and requires complex rules to mark the boundaries of employment. Second, this disparity is exacerbated by separate allowances for investment income and gains, and the facility to 'split' investment income between family members, which is not possible for earnings. Third, individuals are taxed on their nominal income, with no allowance for inflation; this means that some savers who receive low rates of return may pay tax even though the income leaves them no better off in real terms. Fourth, because the tax base excludes 'in-kind' returns such as the benefits of living in owner-occupied housing, it distorts savings decisions across different asset classes.

Capital gains tax applies when an asset is sold or otherwise disposed of (e.g. as a gift) at a profit. The gain is the difference between the asset's value on disposal and its 'base cost' when it was acquired. There is generally no CGT on main homes. Transfers between spouses, and gifts to charities, are made on a 'no gain no loss' basis: this means (in the case of spouses) that the initial base cost carries over until the next disposal. Charities can generally dispose of assets free of CGT. Individuals receive a separate tax-free allowance for gains (the 'annual exempt amount') currently set at $£ 12,300$. Above this, the tax rate depends on the type of asset and the individual's marginal income tax rate. For higher rate taxpayers, the standard rate of CGT is $20 \%$. A reduced rate of $10 \%$ applies to gains made on the disposal of business assets that qualify for business asset disposal relief. ${ }^{5}$ Residential property and carried interest are charged at $28 \%$. CGT is entirely 'forgiven' at death. ${ }^{6}$

The criticisms of CGT are similar to those for income tax. Individuals are taxed on their nominal gain, with no allowance for either inflation or a risk-free rate of return. On the other hand,

\footnotetext{
${ }^{5}$ This relief was previously named 'entrepreneurs' relief' until it was renamed in the March 2020 Budget. The relief is available to individuals when they sell their business, under certain qualifying conditions, up to a lifetime limit of $£ 1$ million (previously $£ 10$ million) in qualifying gains.

${ }^{6}$ Death is not treated as a disposal event, so there is no tax to pay when assets are transferred to heirs. Assets are also 'rebased' to their value on the date of death, so the gains accruing prior to death go permanently untaxed (except in some circumstances relating to gains held over on transfers out of trust and certain types of offshore funds, beyond the scope of this paper).
}

5 
headline rates are much lower than those applied to income, which provides an incentive for individuals to repackage income in the form of gains, especially where business asset disposal relief applies (Miller, Pope \& Smith, 2019; Advani \& Summers, 2020a). These distortions result in significant variation in the effective tax rates paid by individuals with the same total income and gains (Advani \& Summers, 2020b). Additionally, the annual exempt amount is higher than can be justified on administrative grounds, providing an arbitrary benefit to individuals who can diversify their sources of remuneration. Forgiveness on death (compared with CGT on lifetime gifts or sales) creates a 'lock-in' effect that can distort decisions about when to dispose of assets.'

For returns on wealth held in the form of shares, it is also important to consider the impact of corporation tax, which reduces the effective (post-tax) rate of return to shareholders. The magnitude of this effect depends on the extent to which the economic incidence of corporation tax is shared with others such as workers and consumers, which varies depending on market conditions (Fuest, Peichl \&. Siegloch, 2018). Corporation tax is currently charged at a single rate of $19 \%$, having steadily declined from a top rate of over $40 \%$ in the early 1980 s. $^{8}$ The tax treatment of multinational companies has attracted the strongest criticisms. Although this issue is beyond the scope of this paper, it is relevant to observe that the benefit of the low effective corporate tax rates paid by some firms will go partly to shareholders in the form of higher post-tax returns on their investment.

\subsubsection{Taxes on transfers of wealth}

Inheritance tax applies to an individual's net wealth at death (their 'estate'): the point when their assets are transferred to their heirs. The value of most gifts made within seven years before death is also taxed, although sometimes with a discount known as 'taper relief'. Regular gifts out of surplus income are wholly exempt and there are a range of other lifetime exemptions. Transfers to spouses are generally exempt. ${ }^{9}$ Business and agricultural property is not taxed, provided that they meet the criteria for relief. ${ }^{10}$ Individuals receive a tax-free allowance (the 'nil rate band') currently set at $£ 325,000$. This allowance can be transferred to the deceased's surviving spouse if unused on the first death, giving an effective allowance of $£ 650,000$ for married couples or those in a civil partnership or same sex marriage; a complex provision introduced in 2017 raised this to $£ 1$ million per couple if part of that wealth was derived from a residential property and was left to children. Above the allowance, IHT is charged at $40 \%$.

The overarching criticism of IHT is that its design makes it too easy for the wealthy to avoid through straightforward tax planning. The reliefs for business and agricultural property disproportionately benefit the wealthiest; consequently, on average, effective rates of IHT peak at around $20 \%$ and decline to $10 \%$ for estates valued at over $£ 10$ million (OTS, 2018). Lifetime gifts to individuals made more than seven years before death are generally tax free provided the donor is excluded from any benefit. This can reduce the effective rate further and tends to benefit those who can make large gifts early without reducing their standard of living (again typically the wealthiest). ${ }^{11}$ Despite major changes in 2006, trusts still provide additional planning opportunities as well as resulting in increased complexity as some lifetime gifts to trusts are subject to immediate tax. Other devices such as fragmentation of shares through use of family

\footnotetext{
${ }^{7}$ This is particularly significant for assets that qualify for $100 \%$ business property relief for IHT, as well as CGT forgiveness on death. See further OTS (2019).

${ }^{8}$ Over this period there have also been several changes to the scope of the tax base (e.g. in relation to capital allowances).

${ }^{9}$ There are a few exceptions on transfers to foreign domiciled spouses not discussed here.

${ }^{10}$ These criteria are drawn widely: for example, business property relief applies to shares in private trading companies invested on the Alternative Investment Market (AIM), even where the deceased had no involvement in the management of the business.

${ }^{11}$ Those whose major asset is their home cannot effectively give this away if they need to continue living in it, because this would breach anti-avoidance provisions known as the 'reservation of benefit' rules, backed up by the pre-owned assets tax (POAT) rules.
}

6 
investment companies can also reduce IHT while maintaining high levels of control. These aspects combine with more emotive objections to taxes levied on death, to make IHT notoriously unpopular with the public (Shakespeare, 2015).

Stamp duty land tax applies to transfers of residential and commercial property in England and Northern Ireland. It is based on the purchase price of the property and levied on the buyer, although its economic incidence is split between both buyer and seller (Besley, Meads \& Surico, 2014). Tax rates on residential property vary according to whether or not the purchaser is a firsttime buyer, whether the property is an 'additional property' (i.e. a second home or buy-to-let) and (from April 2021) whether the buyer is UK resident or non-resident. The rate schedule is steeply progressive and applies in slices with a top rate of up to $15 \%$ on the value over $£ 1.5$ million or above $£ 500,000$ when the purchase is by a company subject to ATED. From April 2021, the top rate increases to $17 \%$ for non-residents. Separate stamp duty taxes also apply at $0.5 \%$ on the purchase of shares (or options to buy shares) in UK-incorporated companies.

SDLT can be criticised on several grounds. Imposing a tax on transactions distorts the housing market by discouraging people from moving when they otherwise would. This reduction in mobility is also often said to distort the labour market, although Hilber \& Lyytikäinen (2017) find that the tax does not adversely affect job-induced or long-distance mobility. The tax also lacks horizontal equity: a frequent house-mover pays more than a lifelong owner, even if they have the same level of housing wealth. From a public finance perspective, the tax is easy to administer and cheap to collect, but the revenues are highly volatile since they depend on transaction volumes as well as the value of the housing stock. For example, after the Financial Crisis, SDLT revenues from residential property collapsed from $£ 9$ billion in 2007-08 to $£ 4$ billion the following year (HMRC, 2019a).

\subsubsection{Taxes on ownership of wealth}

The UK does not currently have any broad-based tax on the ownership of wealth. However, it has two taxes affecting owners of housing. Council tax applies to residential property in England, Scotland and Wales, ${ }^{12}$ and is loosely based on the value of the house. Although the tax is levied on occupiers, it operates somewhat like a tax on ownership of housing wealth where the property is owner-occupied (although with no deduction for mortgage debt). Where the property is rented, the tenant is liable to pay the tax; however, the landlord (owner) may bear some of the cost in reduced rent. ${ }^{13}$ The tax is collected by local authorities, which have a limited discretion to vary the level of the charge. The rate schedule is fixed by reference to a series of bands that depend on the value of the property in $1991 .{ }^{14}$ There are a series of complex exemptions and reliefs that depend on (amongst other things) whether the property is occupied, the number of occupants, and their incomes.

Criticisms of council tax must be viewed in historical context. The tax replaced the lump sum community charge known as the 'poll tax'; it was not designed, and certainly does not function as, a tax on wealth. Rates are regressive: lower-banded properties face a higher tax rate as a proportion of their value than properties in higher bands, and the top band applies the same charge to all properties above a current value of around $£ 1.5$ million. Moreover, because bands are determined by reference to 1991 property values, subsequent regional variations in house

\footnotetext{
12 There are some regional differences: see further Eiser (2020). In Northern Ireland, the equivalent of council tax is 'rates'.

${ }^{13}$ There is a lack of evidence on the economic incidence of Council Tax, in particular the proportion born by landlords versus tenants.

${ }^{14}$ Except for Wales where revaluation was undertaken in 2003.
} 
prices are not taken into account, mainly to the advantage of those living in London. It is hard to come up with any efficiency or equity justification for this approach to taxing residential property.

The annual tax on enveloped dwellings was introduced in 2013 , with the stated purpose of countering avoidance of SDLT. ${ }^{15}$ It applies to residential properties owned via a company, unless the property is being developed or rented to an unconnected party. ${ }^{16}$ Like council tax, the rate structure applies in bands based on the gross value of the property; however, properties are revalued every five years. The bands are steeply progressive, with charges starting at $£ 3,700$ for properties valued between $£ 500,000$ and $£ 1$ million, and up to $£ 236,250$ for all properties valued above $£ 20$ million. Revenue from ATED was $£ 139$ million in 2018-19 (HMRC, 2019b); although modest, this reflects the very limited number of properties affected. It is relatively straightforward to administer (Troup, Barnett \& Bullock, 2020), although requires filing by a large number of (rental and development) properties that have no tax to pay.

\subsubsection{Taxes on spending wealth}

Value added tax applies to expenditure on most goods and services. It is levied as a percentage of the sale price to consumers. VAT can accordingly be thought of as a tax on the spending of wealth; however, it is also a tax on spending out of income: in other words, it taxes both immediate and deferred expenditure. The main rate of VAT is currently set at $20 \%$; however, a reduced rate of $5 \%$ applies to some goods and services, for example domestic fuel. There are three ways in which expenditure on goods or services may not face any VAT. First, items such as (some) food, children's clothes and books have a zero rate. Second, spending on some items including financial services (e.g. banking and insurance), private healthcare and private education, are exempt. ${ }^{17}$ Third, spending that takes place abroad is effectively outside the scope of the UK VAT system altogether (although a local equivalent may apply).

A common criticism of VAT is that it is 'regressive'. Whether or not this is correct depends on whether its impact is measured with respect to levels of income or expenditure. ${ }^{18}$ Due to the flatrate structure of VAT, it is correct to say that it is less progressive than income tax, a claim which holds regardless of whether income or expenditure is taken as the frame of reference. There does not appear to be any current evidence on the distributional impact of VAT with respect to wealth. A further criticism of VAT is that the different effective rates applied to different types of goods and services distorts consumer choices. It is sometimes argued that reduced or nil rates can be justified on grounds that they improve progressivity, for example in relation to food and children's clothes. However, they are a very expensive and inefficient way of achieving this objective, and various other exemptions (such as financial services, private healthcare and private education) tend to benefit the better-off.

Finally, it is crucial to emphasise that VAT is a tax on expenditure (i.e. out-of-pocket spending); however, an individual can obtain ongoing consumption benefits from the use of durable assets such as housing, cars, boats, artwork, etc. - long after the initial expenditure to acquire them. Ideally, the VAT paid on new items should reflect the consumption benefits that the asset can be expected to yield over its lifetime. But in many cases no VAT has ever been paid on the asset, for example in relation to housing, or any items (such as collectables) produced prior to the introduction of VAT. In other cases, the VAT initially paid on the item when new may turn out to

\footnotetext{
15 In fact, a key driver of 'enveloping' within corporate structures was instead the avoidance of IHT by foreign domiciles; this has subsequently been tackled through separate legislation (known as 'Schedule A') in 2017.

${ }^{16}$ A limited number of other reliefs also apply.

17 The difference between zero-rating and exemption concerns whether or not producers can recover 'input VAT' on their production costs: this distinction is not significant for present purposes.

${ }^{18}$ For a full discussion see Bourquin \& Waters (2019).
} 
underestimate the full value of consumption over its lifetime. ${ }^{19}$ And when VAT increases on new expenditure, this has no impact on the tax paid on consumption of already-acquired durable assets.

\subsection{Options for reform}

Proposals for reforming the UK's existing taxes on wealth are not in short supply. Many of these have a long history, traceable at least as far back as the Meade Report, published in 1978. New recommendations have proliferated in recent years, as taxes on wealth have moved up the political agenda and attracted more attention from policymakers. This trend reflects an emerging consensus that the current system is unsatisfactory in at least two key respects: first, current taxes on wealth are inefficient, as described above; second there is horizontal inequity arising from the under-taxation of returns from wealth compared with those from work. However, the abundance of proposals can make it more challenging to identify coherent directions for reform. When people say that we should 'just reform existing taxes on wealth' rather than implementing a new wealth tax, it is not always clear which set of proposals they have in mind.

To clarify the available options, it helps to group specific recommendations together, since most current proposals turn out to reflect one of two coherent packages for reform:

One package works in the direction of a comprehensive consumption tax (CCT). This approach reflects the premise that an individual's welfare (or ability to pay) ${ }^{20}$ is best reflected by their lifetime consumption i.e. the total amount that they consume over their whole life. In order to raise revenue and redistribute efficiently, the tax system should therefore rely on consumption as the main tax base, but it must avoid distorting individual's choices over when they consume (i.e. whether to spend their savings now or later). In the UK, the Mirrlees Review, published in 2011 , provides the flagship example of this approach. However, the review recognised that consumption is difficult to measure directly and that our current tax system relies heavily on income taxes. Consequently, the package of reforms proposed in Mirrlees sought to achieve consumption tax treatment indirectly, through a combination of reforms to taxes on expenditure and taxes on income/gains, where the latter were designed effectively to serve as 'advance taxes' on future consumption.

Another package of reforms instead follows a comprehensive income tax $(\mathrm{CIT})$ approach. This approach is founded on the view than an individual's ability to pay depends on their control over economic resources, measured by their income. Although there are different ways in which income could be defined for these purposes (Meade et al., 1978, ch.3), the traditional conception of 'comprehensive' income is based on the amount that an individual could consume over a given period without reducing their net wealth. ${ }^{21}$ In policy terms, the amount of tax an individual pays depends on how much income they receive, but 'income' is construed broadly to encompass all forms of accretion to wealth. In addition to the types of income currently charged to income tax, this includes accrued capital gains and any other receipts such as inheritances or gifts.

There are two main conceptual differences between the Mirrlees approach and the CIT approach in relation to taxes on people with wealth:

The first concerns the tax treatment of returns on wealth i.e. savings and investment income, and capital gains. Both the Mirrlees approach and the CIT approach seeks to align tax rates on returns

\footnotetext{
${ }^{19}$ For further discussion of this point see Adam \& Miller (2020).

20 I return to the distinction between welfare and ability to pay in Section 3.1.3 below.

21 This is known as the 'Haig-Simons' comprehensive income definition. More formally, comprehensive income is equal to consumption plus change in net wealth (over a given period), where capital expenditure is amortised rather than immediately expensed.
} 
on wealth with the rates applying to income from work, and to avoid distortions to investment decisions across different types of asset. Both approaches favour an allowance - taking effect as a deduction from the tax base - applied to the nominal returns on wealth. However, the nature and purpose of this allowance differs. Mirrlees favours an allowance for the 'normal rate of return', reflecting the idea that the tax system should leave individuals indifferent as to whether they consume now, or save to consume later. ${ }^{22}$ By contrast, the CIT approach favours an allowance for inflation, reflecting the idea that ability to pay depends on how much an individual's rea/resources have increased.

The second main conceptual difference concerns the tax treatment of transfers of wealth. Under a CIT, all inheritances and gifts should be taxed as income of the donee in essentially the same way as any other income (e.g. earnings), albeit with some provision to smooth the relative 'lumpiness' of such receipts. Under a CCT, there would instead be a strong case for taxing bequests and lifetime gifts as consumption of the donor, and additionally (under a Mirrlees framework) levying income tax as advance tax on the consumption of the donee. However, the Mirrlees Review did not adopt this approach. Instead it recommended a donee-based tax known as a 'lifetime receipts tax' (described in more detail below) with no tax on the donor.

It is important to note that taxes on the ownership of wealth (such as a wealth tax) are not integral to either approach. The CIT approach relies on income as the tax base; the Mirrlees Review aims to approximate a consumption tax base. Neither includes wealth as a distinct tax base. Nevertheless, it remains an open question whether taxes on the ownership of wealth could be motivated on other grounds. The contributors to The Mirrlees Review explicitly rejected any reliance on wealth as a tax base (Banks \& Diamond, 2010; Boadway, Chamberlain \& Emmerson, 2010). However, an earlier review coordinated by the Institute for Fiscal Studies and published in 1978 , known as the Meade Report, concluded in favour of including wealth as a distinct tax base in addition to either consumption or income. I explore the reasons for this divergence in Section 3.1 below. $^{23}$

Having set out this high-level comparison between the Mirrlees and CIT approaches, the following two sub-sections outline the main proposals for reform entailed by each approach, linking these with other proposals that reflect a similar direction of travel.

\subsubsection{Mirrlees Review}

The Mirrlees Review recommends reforming taxes on the returns from wealth by aligning tax rates across all sources of income and capital gains, but with a 'rate of return allowance' (RRA) set by reference to the normal rate of return. The theory behind this approach follows from the aim of achieving comprehensive consumption tax treatment. The idea is to compensate individuals for their choice to save rather than spend immediately, such that the tax system does not influence their decision whether to consume now or later. The RRA does this by providing an allowance equal to the normal or 'risk-free' rate of return, which in simple terms is the interest rate that someone could expect to receive without putting their capital at risk. The Mirrlees Review suggested that this rate should be measured by the yield available on medium-maturity government bonds (gilts). ${ }^{24}$

In implementation, the RRA would operate by allowing individuals to claim a deduction equal to the base cost of their investment multiplied by the normal rate of return over the period when the

\footnotetext{
22 For further explanation, see Section 2.2.1 below.

${ }^{23}$ See also Adam \& Miller (2020).

24 The Mirrlees Review did not define 'medium-maturity'; however, yields on 2-year, 5-year, and 10-year gilts have tended to move closely together, except during major crises where short-term yields exhibit greater volatility. For a comparison see Appendix A Figure $1 \mathrm{a}$.
} 
returns accrued..$^{25}$ Where an asset yields both income and gains, individuals should receive only one allowance set against both forms of return. ${ }^{26}$ If the actual yield after combining income and (realised) gains turned out to have been less than the normal rate of return over the relevant period, the individual would be treated as having made a loss to that extent and this could be offset against other income and gains. It is important to note that alignment with the tax rates on income from work should include NICs as well as income tax; in the case of dividends, alignment should also take account of corporation tax. ${ }^{27}$

In application to income tax, the implementation of this approach varies depending on the type of investment, essentially for reasons of practical administration. For example, given that the interest available from savings held in bank accounts typically does not exceed the normal rate of return, these returns can simply be exempted from tax, equivalent to removing the limit on cash ISAs. For pension savings, Mirrlees recommends retaining the current basic structure, but abolishing the $25 \%$ tax-free lump sum and resolving the anomaly whereby NICs are not charged on either contributions or withdrawals. For most other sources, the standard approach of taxing at aligned rates but subject to an RRA, would apply.

In application to capital gains tax, the Mirrlees approach involves aligning rates with the combined rates of income tax and NICs, but again applying an RRA. This implies a very large increase in headline CGT rates. It is also important to note that, even accounting for the RRA, these reforms would also significantly increase effective rates on capital gains for many individuals. Given that the base cost of investments for many types of gain will be close to zero - for example, on carried interest or many of the gains realised by owner-managers currently qualifying for business asset disposal relief - the RRA available on these investments would also be close to zero. Consequently, a faithful implementation of Mirrlees would - given current tax rates - result in effective top tax rates on gains by private equity managers and (some) business owners exceeding $60 \%{ }^{28}$

In relation to taxes on transfers of wealth, the Mirrlees Review was strongly critical of both SDLT and IHT. They recommended abolishing SDLT altogether, though this was linked with other proposals that would increase council tax on the most expensive properties: see further below. On IHT, Boadway, Chamberlain \& Emmerson (2010) and Mirrlees et al. (2011, ch15) canvassed two main options for reform. Their first preference - albeit with some reservations about administrative feasibility - was to replace IHT with a 'lifetime receipts tax' (described below). ${ }^{29}$ Alternatively, a second-best option would be to overhaul the existing IHT to reduce opportunities for tax planning by expanding the tax base and eliminating reliefs. Neither of these proposals follow from the comprehensive consumption tax approach that forms the centrepiece of Mirrlees. Instead these reforms were motivated mainly by a distinct concern for equality of opportunity. The implications of this objective, in the context of a wealth tax, are discussed further below.

A lifetime receipts tax would be based on the cumulative amount received by the donee over their lifetime, rather than the amount given away by the donor as under the existing IHT. By focusing on the 'windfall' to the donee, this form of tax more aptly emphasises the equality of opportunity

\footnotetext{
${ }^{25}$ If the normal rate of return is negative (i.e. the risk-free rate of return is less than zero) then the application of the RRA would work in reverse, meaning that the taxable return would be larger than the nominal return.

${ }^{26}$ Administratively, the reporting requirements would look similar to those already in place for CGT, except that it would become necessary to report the base cost of investments for income tax as well.

${ }^{27}$ This requires an assessment of the economic incidence of employer NICs and corporation tax. For details on the (empirical) challenges that this involves, see further Advani \& Summers (2020b).

${ }^{28}$ This accounts for income tax (at 45\%), plus employer and employee NICs (combined 15.8\%). The headline rate at personal level would be lower in order to account for corporation tax paid at firm level.

${ }^{29}$ This policy has also been proposed on a number of other occasions, including by Resolution Foundation and IPPR (Corlett, 2018; Dolphin, 2010).
} 
motivation (Sandford, 1987; Bird-Pollan, 2017). Unlike the UK's existing IHT, which only taxes lifetime gifts if made within seven years prior to death, a lifetime receipts tax would draw no distinction between inheritances and gifts regardless of when they were made. ${ }^{30}$ However, the tax base for these receipts would be distinct from other taxable income and gains and subject to a separate lifetime allowance. I discuss separately below the possibility of incorporating inheritances and gifts received within the income tax base of the donee.

The Mirrlees Review also recommended extensive reforms to council tax, although these were not conceived in terms of a tax on ownership of wealth. Instead, they focused on two other aspects of residential property. First, houses provide a home to live in: the occupier consumes housing services. Mirrlees et al. (2011, ch.16) recommended that this consumption value be taxed at a flat annual rate equivalent to VAT based on the property's rental value (known as 'housing services tax'). Second, houses provide an investment: owner-occupiers could alternatively rent their house to someone else, and the house may gain in value. This calls for taxing housing as a return on wealth received by the owners, based either on the actual rental income (if the property was let) or an imputed rent (if owner-occupied), ${ }^{31}$ plus any capital gain on sale. However, these returns would again be subject to an RRA equivalent to the normal rate of return on the initial purchase price.

In combination, these two new forms of tax on residential property would imply a huge increase in tax on owner-occupiers compared with the status quo under council tax. For example, consider a property in the London Borough of Westminster worth $£ 1$ million, with a rental yield of $4 \%$ $(£ 40,000)$. The occupier currently pays around $£ 1,500$ per year in council tax. Under a housing services tax set equivalent to VAT (at $20 \%$ ) this would rise to $£ 8,000$ (i.e. $0.8 \%$ of the value of the property). On top of this, the owner would pay tax on the actual or imputed rental value of the property $(£ 40,000)$, added to their taxable income. Since the normal rate of return is currently close to zero, the deduction of the RRA would be approximately nil. Consequently, if the owner was a higher rate taxpayer, they would pay income tax of $£ 16,000$ (at the margin). For an owneroccupier, who would pay both the housing services tax and income tax on the imputed rent, their total tax bill would therefore rise to $£ 24,000$ in respect of this property. ${ }^{32}$

Recognising the step change in tax liabilities that this approach would entail, Mirrlees et al. (2011, ch.16) suggested that housing services tax initially be set at a rate somewhat less than the equivalent rate of VAT (a rate of $12.5 \%$ was estimated to achieve revenue-neutrality with the existing council tax), and also did not recommend the actual implementation of an additional tax on the imputed rent of owner-occupiers. However, these concessions were explicitly born out of political expedience rather than a principled position. One must acknowledge that the logic of the Mirrlees approach is quite radical in its application to housing. This mostly reflects the fact that owner-occupied housing is grossly undertaxed in our current system.

The Mirrlees Review also recommended a significant expansion of the VAT base. All goods and services that currently receive a reduced or zero rate, or are exempt, would instead be charged at the main rate of $20 \%$. Consequently, VAT or an economic equivalent would be paid in full on (amongst other items): financial services, private healthcare and private education. These listed

\footnotetext{
${ }^{30}$ However, there is nothing inherent in a donor-based tax that requires it to leave most lifetime gifts tax free. In the UK, the donor-based capital transfer tax that operated from 1974 until 1986 was charged on all lifetime gifts and bequests above a lifetime allowance.

${ }^{31}$ To understand why a tax on imputed rent is required in addition to a tax on consumption of housing services for owner-occupiers, it is important to recall that under Mirrlees, consumption is effectively taxed in two stages: first through income tax and CGT as partial 'advance taxes' on consumption, and then the remainder through VAT (or its equivalent) when consumption actually occurs. In relation to owneroccupied housing, the income and consumption arise simultaneously.

32 This further assumes that the property did not increase in value over the year. If it did, then upon realisation the owner would pay CGT on this gain at a rate of over $50 \%$ (given alignment with the current combined rates of income tax and NICs).
} 
expenditures are likely to be disproportionately concentrated amongst the wealthy, so this element of reform could play a role akin to an additional tax on spending wealth. On the other hand, the expansion of the VAT base would also entail application of the $20 \%$ rate to (amongst other items) food and children's clothing, which it would be more difficult to characterise in these terms. As discussed further below, the Mirrlees Review did not make any recommendations to increase taxes on the consumption of durable assets other than housing, leaving a gap where these assets were undertaxed (or not taxed at all) when new.

\subsubsection{Comprehensive income tax}

Under a CIT approach, all income from wealth and (accrued) gains would be taxed at the same headline rates as income from work, but with an allowance for inflation. Just as with the approach in Mirrlees, alignment should take account of NICs as well as income tax, and corporation tax in the case of dividends. The key difference is that under a CIT the allowance would be for inflation instead of the normal rate of return. Again, to implement the allowance, individuals would claim a deduction equal to the base cost of their investment multiplied by the rate of inflation over the period during which income and/or gains accrued. In the case of capital gains tax, this was the approach used previously in the UK under indexation allowance, which applied (in full) from 1988 to $1998 .{ }^{33}$ A return to this approach was recently proposed by the IPPR (Nanda \& Parkes, 2019).

In relation to taxes on transfers of wealth, a CIT approach implies that inheritances and gifts should be taxed on the donee in the same way as other forms of income i.e. included in the income tax base. ${ }^{34}$ This gives rise to some challenges resulting from the 'lumpiness' of these types of receipt, but Meade et al. (1978, ch.7) identify several possible solutions using different approaches to averaging; the policy would be otherwise relatively straightforward to implement from an administrative - if not political - perspective. ${ }^{35}$ Although proposals have been made along these lines in the past (Goodhart, 1988; Robinson, 1989), recently the option of taxing inheritances and gifts as income has not received as many backers as the lifetime receipts tax. ${ }^{36} \mathrm{It}$ is difficult to discern the reasons for this, but a relative lack of international examples - compared with a lifetime receipts tax - may be one explanation.

A CIT approach also implies that council tax should be replaced with a tax on the imputed rent of owner-occupied properties, although allowing a deduction for mortgage interest as an expense incurred in obtaining this benefit. The net rent would be aggregated with the individual's other sources of income and gains and taxed at their standard income tax rates. This approach would effectively mark a return to the old 'Schedule A' charge to income tax although with an additional allowance for inflation. ${ }^{37}$ Schedule $A$ was abolished in 1963, although the associated mortgage deduction was only finally phased out in April 2000. Perhaps scarred by this experience, there do not appear to have been any recent proposals for a return to this approach, although it has some affinity with the tax on imputed rent canvassed (but not recommended) in the Mirrlees Review.

\footnotetext{
${ }^{33}$ However, during this period, although CGT rates were aligned with income tax rates, this alignment did not take into account NICs.

${ }^{34}$ The Meade Report highlighted several options for the tax treatment of the donor in these circumstances (Meade et al., 1978, ch.3); however, typically it is assumed that the donation would be treated as expenditure rather than a subtraction from the donor's income, so would have no tax consequences for the donor under CIT treatment.

${ }^{35}$ Challenges would remain in relation to trusts where the wealth could be held indefinitely in that vehicle but accessed by beneficiaries. Issues such as how gifts between spouses and gifts to non-residents should be taxed would also need consideration.

${ }^{36}$ Resolution Foundation modelled the revenue that such a policy could raise but did not adopt it as their central recommendation (Corlett, 2018).

${ }^{37}$ For a full history of the Schedule A charge to income tax, see Chick (2020).
} 


\subsubsection{Reforms merited under either approach}

It is important not to overstate the differences between the consumption tax treatment recommended by the Mirrlees Review, and a comprehensive income tax approach. Below I outline a series of reforms to our existing tax system that would be merited under either approach. From a policy (if not political) perspective, these reforms are the 'easy wins' in the sense that they correct anomalies in our current approach to taxing wealth that cannot be justified on any coherent basis.

Both the Mirrlees and CIT approaches recommend full alignment of the effective tax rates on returns from wealth (income and gains) with the rates applicable to earning from work. In both cases, this includes levying an equivalent of NICs on investment income and capital gains, accounting for both the employee and employer components. The main difference between the two approaches is whether to give an allowance for the normal rate of return or for inflation. However, this distinction has become relatively unimportant under current economic conditions, where both rates are very low by historic standards: Figure 1 (Appendix A) shows a comparison since 1970 . To be sure, the difference between these rates has been substantial at some points in the past, and could be again, but at the time of writing the issue of what type of allowance to give is of second-order importance compared with the disparities in headline rates across different forms of income and gain.

Consequently, both the Mirrlees and CIT approaches would result in significantly higher effective tax rates on returns on wealth than at present. An exception is for assets that yield a low nominal return (less than or on par with inflation or the NRR) such as savings held in bank accounts, for which the tax rate would decrease; however, for most people these returns are already taxexempt if held in ISAs. In some cases, the tax increase resulting from implementation of either the Mirrlees or CIT approach would be very large, particularly on dividends received by ownermanagers and associated gains, where the low base cost of the original capital investment means that only a small allowance would be warranted irrespective of which approach was adopted. Of course, this reflects the fact that such returns are typically not really returns on wealth at all, but rather returns to the owner-manager's own labour inputs (Advani \& Summers, 2020a). The effect on returns on genuine capital investments would be less marked although still substantial (see Appendix B for an example).

Turning to the details of our existing CGT, several aspects cannot be justified on any principled basis. Every report that has considered the point recommends that there should be no forgiveness of CGT on death. ${ }^{38}$ There is not complete consensus on how this reform should be implemented: transfers on death could be treated as a disposal event, such that CGT would be payable immediately; alternatively, transfers to heirs could be on a 'no gain no loss' basis, as applies for spousal transfers at present. ${ }^{39}$ But it is clear that the gain accruing before death should be brought within CGT one way or other. Another anomalous aspect of CGT is the separate tax-free allowance given in addition to the personal allowance for income tax; it follows from the aim of aligning tax rates on income and gains that these allowances should be merged, or at least that any separate allowance should be restricted to an administrative de minimis. The Office of Tax Simplification (OTS) has recently been tasked with evaluating this and other minor distortions to the tax treatment of capital gains (OTS, 2020).

The Mirrlees Review diverges from the CIT approach in its first-best proposal for taxing inheritances and gifts. Under a CIT approach these receipts would be aggregated with the other

\footnotetext{
${ }^{38}$ See for example Mirrlees et al. (2011, ch.15); Adam, Emmerson \& Roantree (2013); Corlett (2018); APPG (2020). The Office of Tax Simplification (OTS) was also critical of CGT forgiveness on death but stopped short of recommending its complete abolition (OTS, 2019).

${ }^{39} \mathrm{~A}$ disadvantage of the latter approach is that it would result in a distortion between lifetime gifts, which are generally charged to CGT immediately on the disposal, unless gift holdover relief were extended. 14
} 
income of the donee, whereas Mirrlees provisionally recommends a separate lifetime receipts tax. However, neither approach provides any justification for the anomalies under the existing IHT. It is consistent with both approaches that if IHT is to be retained (for example, because donee-based alternatives are regarded as administratively or politically infeasible), the tax base should be expanded significantly by abolishing reliefs for agricultural and business property and imposing the tax on all lifetime gifts over a limited annual allowance. The 'seven year' rule would therefore be abolished. ${ }^{40}$ These and other related reforms were recently recommended in a report by the All Party Parliamentary Group on Inheritance and Intergenerational Fairness (APPG, 2020); ${ }^{41}$ they are also reflected in the 'second-best' option recommended by Mirrlees et al. (2011, ch.15).

The Mirrlees Review firmly recommended the abolition of SDLT and other stamp duties (Mirrlees et al., 2011, ch.15). There are no grounds for retaining these taxes under a CIT approach either. Indeed, it is hard to think of any economic or philosophical rationale for using arms-length transactions as a tax base. However, there are some practical and distributional reasons why it would be unwise to abolish SDLT without making associated reforms to the taxation of residential property. The existing tax does at least have the merit of being easy and cheap to administer. The design of SDLT also ensures that it has a very low 'tax gap' (Troup, Barnett, \& Bullock, 2020) and there are limited opportunities for planning, although there remains a strong incentive to avoid SDLT by transferring ownership of rental properties via shares in a holding company.

Consequently, if SDLT was abolished, there would be a very strong case for replacing it with a progressive annual property tax. The obstacles to reforming council tax to serve this purpose are purely political. It is impossible to mount any plausible defence of the reliance on 1991 valuations. There is broad consensus that the rate structure should be overhauled so that it is no longer regressive. Mirrlees et al. (2011, ch.16) recommended a single flat rate, initially set at $0.6 \%$ of the property value (which is lower than would be required to achieve equivalence with VAT). The Resolution Foundation, amongst others, have proposed that rates should rise progressively (Corlett \& Gardner, 2018). Given that the contributors to the Mirrlees Review also reflected positively on the idea of an additional annual tax on the most expensive properties (Boadway, Chamberlain \& Emmerson, 2010), in practice there is not much divergence here. The implementation of these reforms could now also look to ATED as a suitable legislative and administrative model. ${ }^{42}$

In summary, many of the same reforms to existing taxes on wealth are merited under both the Mirrlees and CIT approaches, because our current system contains a raft of anomalies that have no principled justification. In other words, despite their differences, the two reform packages outlined above have a lot more in common with one another than they do with the design of our existing taxes on wealth. ${ }^{43}$ For an illustration, see Appendix $\mathrm{B}$, which compares all three approaches in application to a simple example. It is hard to avoid the conclusion that the reasons for the present failure to reform existing taxes on wealth have more to do with politics than with economic principle. ${ }^{44}$ This insight has important implications for the role of a wealth tax, which I consider below.

\footnotetext{
${ }^{40}$ The comprehensive taxation of lifetime gifts on the donor would mark a return to the capital transfer tax that operated from 1974 to 1986: see further Tiley (2007).

${ }^{41}$ These proposals included the abolition of the nil rate band on lifetime gifts, and abolition of almost all reliefs other than the spouse exemption and charitable exemption.

42 ATED could relatively easily be converted into a progressive replacement for council tax, simply by removing the restriction to properties owned via companies and relief for rented properties.

${ }^{43}$ This is especially true under current economic conditions, where both the inflation rate and normal rate of return are low. See further Appendix B, which compares the three approaches in application to a simple example.

${ }^{44}$ For further discussion of the politics of taxing wealth, see Perrett (2020) and Clark et al. (2020). 15
} 


\section{The role of a wealth tax}

Having reviewed the leading proposals for reforming existing taxes on wealth, this section considers two main possible roles for a wealth tax. In principle, a new broad-based tax on the ownership of wealth could be introduced either as well as or instead of these reforms.

In the following analysis, I assume that a wealth tax has two defining characteristics. First, it is based on the ownership of wealth i.e. the amount of tax that a person pays depends on how much wealth they own. Second, the tax is at least to some extent broad-based, in that it applies to more than one type of asset; this distinguishes a 'wealth tax' (properly so-called) from, for example, a narrower 'property tax'. Beyond this, a wealth tax is consistent with a wide range of design choices; these are considered in detail in other papers for this project. For present purposes, I distinguish two key design dimensions:

A wealth tax could be one-offor recurrent. Typically, recurrent wealth taxes have been levied on an annual basis, although in principle they could recur over a longer or shorter interval. It is important to emphasise that the distinction between a one-off wealth tax and an annual wealth tax concerns the recurrence (or otherwise) of assessment, rather than the process of administration and collection. It would be possible to have a one-off assessment of wealth where the resulting tax liabilities were collected in instalments over several years and may still be due on an annual basis. The point is that the amount of tax that an individual would pay would depend on their wealth at the time of the initial assessment rather than being re-assessed each year. ${ }^{45} \mathrm{The}$ West German capital levy that operated after the Second World War was of this type (O'Donovan, 2020).

A wealth tax could also be comprehensive or partial. This distinction refers to the scope of the tax base and the rates applied to different types of asset. A comprehensive wealth tax is one that captures all forms of wealth (although this is not straightforward to define: see Chamberlain, 2020) and taxes them at a common rate. There are two respects in which a wealth tax may be partial. First, some types of asset may be exempted from the tax base altogether; second, different types of chargeable asset may be charged at different rates. Such differential rates could stem either from differences in the headline rates applied to different types of asset, or (more likely) from differences in effective rates that result from valuation discounts or other reliefs.

These two key design dimensions may generate different implications for the role of a wealth tax. The following two sub-sections consider each possible role in turn.

\subsection{As well as reforming other taxes on wealth}

Suppose that the reforms to existing taxes on wealth recommended either by the Mirrlees Review or under a CIT, were implemented in full. Would there be anything left for a wealth tax to do? Put another way: is there any justification for using wealth as a tax base, as distinct from taxing the income from wealth, the consumption that can be obtained from spending and enjoying the use of wealth, and transfers of wealth across generations?

\footnotetext{
${ }^{45}$ There could also be an intermediate design involving a one-off initial assessment but an asymmetrical adjustment, operated as a relief, where an individual's wealth subsequently fell as the result of a decline in the value of their assets. This approach may avoid some of the strong objections to one-off assessment with annual collection on grounds of ability to pay.
} 
One motivation frequently cited in connection with a wealth tax is the desire to reduce wealth inequality (Saez \& Zucman, 2019; Rowlingson, Sood \& Tu, 2020). ${ }^{46}$ However, there are multiple different reasons why someone might be concerned about wealth inequality, and it is helpful to distinguish these. From a philosophical perspective, objections to wealth inequality can roughly be separated into concerns about the processes by which wealth has been accumulated and the outcomes reflected in the current distribution of wealth. ${ }^{47}$ In the discussion that follows, the first two sets of argument ('correct the past' and 'ongoing corrective') reflect process-based concerns with the current distribution of wealth, whereas the third argument ('wealth affects welfare') reflects an outcome-based concern.

A further kind of objection to wealth inequality focuses not just on the amount of wealth that each individual has, but more specifically on the negative consequences that may flow from maintaining large differences in wealth between individuals (Scanlon, 2018). For example, a commonly cited concern is with the excess concentration of political power and influence amongst the wealthy, which is possessed in virtue not merely of being wealthy, but through having more wealth than others. I do not elaborate a justification for a wealth tax based exclusively on reducing differences in wealth, although this motivation is considered by Adam \& Miller (2020) under the rubric of negative externalities generated by extreme wealth.

\subsubsection{Correct the past}

The proposals for reforming existing taxes on wealth considered in Section 2 above - including both the Mirrlees and CIT approaches - are wholly prospective in outlook. The Mirrlees Review sought to design an optimal tax system starting nowi.e. assuming that we are happy with current distribution of wealth, which will represent individuals' starting points under the new system. The policies recommended by Mirrlees et al. (2011, ch.20) do not make any attempt to correct for past distortions in the distribution of wealth created by the old tax system. Some individuals may currently own more wealth than they 'should' have (under an optimal tax system) because - for example - their capital gains were undertaxed or they escaped paying any tax on inheritances or gifts received in the past. Moreover, proposals for reforming existing taxes on wealth also typically leave unaddressed other concerns about the processes by which past wealth has been accumulated: for example, as the result of market failures or historic injustices.

Consequently, even once we have managed to design and implement the optimal tax system going forwards, we might still want to implement measures to 'correct the past'. This would be like pushing the 'reset' button before booting up the new system. However, there are undoubtedly a multitude of things that have gone wrong in the past, that we may wish to correct for. Ideally, we would rectify each of these missteps directly. However, that is clearly infeasible in many cases. Even if we could agree in principle about which missteps should be corrected, we lack the information required to such corrections at an individual level. In these circumstances, the tax system might provide the most appropriate means for rectifying past wrongs. Indeed, even the libertarian philosopher Robert Nozick recognised an in-principle case for using the tax system in this way. ${ }^{48}$

\footnotetext{
${ }^{46}$ In a survey of UK public attitudes by Rowlingson, Sood \& Tu (2020) conducted in July 2020, respondents were shown six arguments in favour of a wealth tax and asked which (if any) they supported. Of these arguments, respondents were most likely to support the argument that 'the gap between rich and poor is too large' (given by $36 \%$ of respondents).

47 This distinction between process-based and outcome-based concerns reflects Nozick's taxonomy of 'historical' and 'end-state' theories of distributive justice, respectively (Nozick, 1974, ch.7).

${ }^{48}$ As Nozick put it, 'Although to introduce socialism as the punishment for our sins would be to go too far, past injustices might be so great as to make necessary in the short run a more extensive state [through tax and transfer payments] in order to rectify them.' (Nozick, 1974, ch.7, pp.231).
} 
Whether a wealth tax is an appropriate tax policy tool for effecting corrections to the past depends firstly on whether it is a fair assumption that those with currently high levels of wealth are more likely to have been the beneficiaries of past inefficiencies or injustices than those with currently low levels of wealth. One would also need to be assured that current wealth provides a sufficiently strong predictor of these inefficiencies and injustices that this approach would be justified despite that it would also inappropriately tax individuals whose wealth had been accumulated in a manner that did not warrant such a correction (for example, the archetypal 'rags to riches' entrepreneur).

If one wished to use a wealth tax to correct the past (at least in part), this would have various implications for how the tax should be designed. First, if one was only concerned with past inefficiencies and injustices, a one-off wealth tax would be more appropriate than a recurrent levy, because it exclusively affects 'old capital'. In other words, $100 \%$ of the tax base would be wealth accumulated under the old system. An annual wealth tax would be less well-targeted for this purpose, as over time it would capture more and more new capital (for example, savings out of current labour income) that had been accumulated under the newly reformed system.

Second, as a tool for correcting the past, a wealth tax ought to have a comprehensive base, unless there are good reasons to think that wealth held in particular forms are more likely to have benefited from the missteps that the tax is seeking to correct. It is true that some past problems of under-taxation have been focused on particular types of asset: for example, main residences that have been exempt from CGT. However, for the purpose of correcting the past, it would not follow that a wealth tax should target specifically these assets in the hands of their current owners, because the proceeds of previously under-taxed gains (or other tax inefficiencies), may have since been invested into other forms. Consequently, it would not be possible to target past inefficiencies by restricting a wealth tax only to the asset types that have been undertaxed in the past.

\subsubsection{An ongoing corrective}

What if it is the case not only that wealth has become too unequally distributed as a result of past inefficiencies and injustices (as outlined above), but also that these or other unjustified processes are continuing to drive an overconcentration of wealth? To the extent that such processes result from imperfections in our existing taxes on wealth, these may be corrected by implementing the reforms recommended under the Mirrlees Review or a CIT approach i.e. they do not call for the additional introduction of a wealth tax. However, even if such reforms were implemented in full, there may still be a residual concern that other processes will continue to operate - across various aspects of our economy and society - which tend towards unjustified sources of wealth accumulation. Could a wealth tax play a role in 'actively managing' such accumulations?

Various specific concerns may be raised in this regard. For example: market failures arising from excessive and uncontrolled market power; the impact of expansionary monetary policy (low interest rates and quantitative easing) on asset prices; superstar effects and impact of automation on the distribution of incomes; rent extraction through political influence on policymaking; or dynastic wealth accumulation through inheritances and gifts (which would not be reduced to zero even under proposed reforms to inheritance tax). All of these examples are contestable, both in terms of the magnitude of their impact on the distribution of wealth and the extent to which wealth that is accumulated as a result of these processes is deserved or otherwise justified. Others may cite different processes giving cause for concern.

For present purposes the question is whether, if these are valid concerns, a wealth tax could provide a suitable ongoing corrective. The most obvious point to make in this regard is that a wealth tax is, by design, insensitive to the source of wealth. For example, it treats wealthy monopolists and heirs to dynastic fortunes the same as competitive entrepreneurs. Ideally, one would use more targeted public policies to address ongoing concerns about the processes of 
wealth accumulation. Nevertheless, some people hold the view that in cases of extreme wealth it is reasonable to presume that something must have gone wrong in the processes by which it was accumulated i.e. that extreme wealth is itself indicative of a failure of market mechanisms or government intervention. ${ }^{49}$ This line of argument appears to lie behind the preference of some economists for a wealth tax that would target the very wealthiest individuals in particular (Saez \& Zucman, 2019)..$^{50}$

\subsubsection{Wealth affects welfare}

The amount of wealth that an individual has might provide information about their 'welfare' or 'ability to pay' tax that cannot be gleaned simply from looking at how much income they receive, or how much they consume, even over a lifetime. ${ }^{51}$ The notion of ability to pay has a strong pedigree in tax policymaking; it was the first of Adam Smith's four canons of taxation in The Wealth of Nations. In the Meade Report, the idea of ability to pay was referred to as 'taxable capacity' and it formed the organising principle on which the report's policy recommendations were based (Meade et al., 1978, ch.3). The authors' view that wealth indicated taxable capacity distinct from consumption motivated their conclusion that the tax system ought to include both consumption and wealth as tax bases. In turn, this led the report to recommend the introduction of an annual wealth tax in addition to a consumption tax (Meade et al., 1978, chs10 \& 16).

Although the view that wealth indicates taxable capacity distinct from consumption has some intuitive appeal, the notion of taxable capacity is not at all straightforward to define. The authors of the Meade Report acknowledged this. To illustrate the difficulty, they considered an example involving Mr Smith and Mr Brown (Meade et al., 1978, p.34). In the example, both men start with equal wealth and income, but $\mathrm{Mr}$ Smith chooses to save his income whereas Mr Brown spends it. Mr Smith now has more wealth than Mr Brown, but the puzzle is: which of them has more taxable capacity? As the authors of the Meade Report put it: 'Both have the same power of command over resources. Can the fact that $\mathrm{Mr}$ Smith chooses to use this power one way and Mr Brown in another way affect their present capacities to pay tax?'

There are several parts to this puzzle. Before addressing the one that is of direct relevance for present purposes, some ground-clearing is required. First, the example only has force where $\mathrm{Mr}$ Brown spends in such a way that dissipates his wealth: for example, on holidays or meals out. If instead he spends on durable assets - even ones that also provide him with consumption benefits, such as a car or yacht or artwork - then his wealth will not have decreased as a result of the purchase, except to the extent that the asset depreciates over time and there is an opportunity cost of the money used (which could otherwise have been invested). ${ }^{52}$ At certain high levels of wealth, it seems likely that a large proportion of spending takes forms in which wealth is preserved or increased rather than dissipated; if so, the example may not take us very far in the real world of the super-rich.

Second, although this example primes us with the intuition that Mr Smith's choice to save rather than spend should not leave him liable to additional tax, it is reasonable to ask how widespread such examples are in real life. If it turns out that there is not much variation in the savings decisions of individuals at similar initial levels of wealth and income, then there may not be many cases in which the horizontal inequity posited by the example actually bites. On the other hand, it is not

\footnotetext{
${ }^{49}$ This idea is reflected in the (much-contested) slogan: 'every billionaire is a policy failure'.

50 In the US context, Saez and Zucman recommend a wealth tax that would only start at a threshold of \$50 million, with the highest rates applying to individuals with fortunes exceeding \$1billion.

${ }^{51}$ For now I use the terms 'welfare' and 'ability to pay' interchangeably; below I explain the different ways of thinking about tax policy that each of these reflect.

52 Although this opportunity cost does not detract from Mr Brown's nominal wealth, it would over time cause his wealth to fall behind Mr Smith's, on the assumption that the latter received the normal rate of return on his savings whereas the durable assets purchased by Mr Brown did not.
} 
sufficient to point a lack of variation in savings rates (by initial wealth and income) under our current system as decisive, if future savings behaviours would be substantially affected by reforms that increase the effective tax rate on savings. Still, the available evidence indicates that taxes only have a very weak effect on savings rates in practice (Advani \& Tarrant, 2020).

Leaving these two issues aside, the answer to this puzzle depends mainly on whether one looks at the information as a snapshot or over the lifecycle. Viewed as a snapshot, it appears that if ability to pay depends on income then Mr Brown and Mr Smith should pay the same tax; if it depends on wealth, then Mr Smith should pay more tax than Mr Brown; and if it depends on consumption, then Mr Brown should pay more tax than Mr Smith. However, the Meade Report's authors pointed out that when considered from a lifecycle perspective these positions may even out, on the assumption that Mr Smith eventually consumes his wealth. The residual case for thinking that wealth indicates taxable capacity is if the wealth conferred some additional benefit on Mr Smith besides his eventual consumption of it. The Meade Report concluded that it did, on the basis that wealth also provided the holder with 'security, independence, influence and power' (Meade et al., 1978, p.351).

The Mirrlees Review rejected the Meade Report's conclusions about the distinctive benefits of holding wealth. To understand the root of this divergence, it is important to appreciate the differences in methodology between these two landmark reviews. Contributing to the Mirrlees Review, Banks \& Diamond (2010, p.610) considered but explicitly rejected 'the Meade Report view ... that taxes should relate monotonically to some measure of taxable capacity'. They argued that: 'In addition to finding taxable capacity not well-enough measurable and not sufficiently uniformly evaluated to be usable for this purpose, we also do not see an underlying normative basis for reaching the conclusion that taxes should be related to taxable capacity without full consideration of the equilibrium consequences [for social welfare] of following such an approach.' Instead they concluded that 'the starting place for thinking about taxation should be the impact of taxes on the utilities of people in the economy', reflecting the economic approach of optimal tax theory.

Under the optimal tax approach adopted in the Mirrlees Review, the goal of tax policy is to maximise social welfare, defined as the weighted sum of individuals' welfare. In turn, it was assumed that an individual's welfare depends exclusively on the amount they consume (increases welfare) and how much they work (decreases welfare) (Banks \& Diamond, 2010). However, one might reasonably question this assumption. What if - as Meade posited - wealth provides additional welfare-enhancing benefits beyond the consumption that it funds (even over a lifetime): for example, benefits like security, independence, influence and power? If so, these benefits are not accounted for by the definition of welfare that drives the policy recommendations of Mirrlees - including the review's rejection of the case for an annual wealth tax (Mirrlees et al., 2011, ch.15).

It will be apparent from this chain of argument that we are essentially back to the debate about taxable capacity with which the Meade Report was concerned, except now under the guise of defining welfare. For this reason, the authors of the Mirrlees Review did not succeed in sidestepping the difficulty of defining taxable capacity; they just reframed the same problem (see further Kay, 2010)..$^{53}$ If, as the Meade Report concluded, wealth is relevant to taxable capacity (distinct from consumption), this is surely because it is relevant to welfare (distinct from consumption). The issue must be resolved either way. Whereas the Meade Report argued for its conclusion that wealth was relevant to taxable capacity, the Mirrlees Review merely stipulated

\footnotetext{
${ }^{53}$ As Kay (2010, pp.660-661) put it when commenting on Banks \& Diamond (2010): 'I cannot imagine that it would be easier to secure agreement on the definition of utilities [welfare] than on the definition of taxable capacities [ability to pay]: indeed, it is likely that the two definitions would be very similar. I believe it is difficult to argue that it is possible to define utilities but not to define taxable capacities.' 
that wealth was not relevant to welfare, in the way that it defined individual welfare in the social welfare function.

In this respect, the policy question of whether an annual wealth tax can be justified in addition to comprehensive consumption tax treatment seems to turn on whether wealth confers benefits on individuals beyond the consumption that it funds: and this is so regardless of whether the puzzle is framed in terms of taxable capacity or welfare. The difficulty is that there is currently not much empirical evidence on this question, although there is some suggestion in the empirical literature on estate taxes that 'wealth as welfare' could explain (part of) the observed desire to retain control of wealth whilst alive (Kopczuk, 2007; Kopczuk, 2013). Given its potential importance in shaping the future direction of optimal tax theory - on which the tax policy prescriptions of economists depend - this would be a useful area for further research.

Notwithstanding this evidential uncertainty, if a wealth tax were justified on the basis that it affected taxable capacity or welfare distinct from consumption, this again has various implications for the design of the tax. First, it ought to be recurring rather than one-off, on the assumption that the added benefits of wealth (over consumption) would persist for those continuing to hold wealth. Second, the tax should be comprehensive unless there is reason to believe that particular types of asset are more likely to confer the relevant benefits (such as security, independence, influence and power) than others. Again (as with correcting the past), it seems plausible that some particular types of asset could be singled out, at least from a static perspective: for example, owning a newspaper business may yield more influence and power than merely owning houses. On the other hand, from a dynamic perspective it may be unwise to differentiate tax treatment on this basis.

Finally, in relation to the CIT approach to reforming existing taxes on wealth, one might reasonably ask about taxable capacity from another perspective: does wealth indicate ability to pay distinct from income? If we take taxable income from a snapshot (annual) perspective, it seems quite obvious that wealth provides additional information about ability to pay - although even this claim is somewhat in tension with the liquidity concerns that are often raised when a taxpayer has high wealth but low income (Loutzenhiser and Mann, 2020). Over a lifetime, the difference between (comprehensive) income and final wealth is by definition consumption (excluding bequests).

\subsection{Instead of reforming other taxes on wealth}

Suppose that a government wished to implement the reforms to existing taxes on wealth recommended by the Mirrlees Review or a CIT, but that it was not able to do so - perhaps because those reforms appeared infeasible, either administratively or politically. Could a wealth tax provide an alternative?

There are several steps to follow in answering this question. First, it is important to be clear about the objectives of the desired reforms to existing taxes on wealth (that, by hypothesis, have been ruled out on account of their infeasibility). Second, would a wealth tax help to achieve those objectives? If the answer is no - or even worse, if it would be antithetical to those objectives then a wealth tax is not really an 'alternative' at all, but rather would be doing something different. Third, to the extent that a wealth tax couldadvance similar objectives, would introducing this new tax be any more feasible - administratively and/or politically - than the reforms to existing taxes that it would stand in for?

As part of this assessment, it is also necessary to consider the design of the wealth tax that would be needed to achieve (as closely as possible) equivalence with the results of reforming existing taxes on wealth. ${ }^{54}$ If the tax was aiming to provide a substitute for reforms to other recurrent

${ }^{54}$ Auerbach (2019) provides a useful overview of the general issues that can arise in this context. 
annual taxes (such as income tax or council tax), a recurring rather than one-off wealth tax is likely to be more appropriate. In principle, it is possible that a partial rather than comprehensive wealth tax could serve as a substitute for reforms to existing taxes on wealth, where the flaws in the current system concern particular undertaxed asset classes; however, as I explain below, such an approach is likely to be impractical.

Reforms to existing taxes on returns on wealth (income tax and CGT) should aim at two key objectives. The first is to achieve neutrality of tax treatment across asset classes and compared with labour income ('source neutrality'). This objective is shared by both the Mirrlees and CIT approaches. The second objective is to achieve neutrality in the timing of consumption, or in other words to ensure that the tax system does not distort individual's choices about whether to consume now or later ('timing neutrality'). This is a key objective under the Mirrlees approach only.

A wealth tax could go some way to improving source neutrality with respect to labour income by reducing the net-of-tax return on wealth; however, it would not do this as effectively as alignment of income tax and CGT rates on all sources of income and gains, because it would still leave some 'excess' returns on wealth relatively undertaxed. A comprehensive wealth tax would not assist source neutrality across asset classes; it would merely add another layer of taxation on top of existing distortions. A partial wealth tax that focused on assets that are currently undertaxed (such as housing) could potentially rebalance tax treatment across asset classes. However, it is unclear why one would want to use a wealth tax for this purpose: for example, the administrative and political hurdles of implementing a tax on net housing wealth do not appear any easier than imposing CGT (and/or a charge on imputed rent) on main homes.

A wealth tax would worsen timing neutrality. The existing tax treatment of savings and investment income and gains already incentivises individuals to consume now rather than later and hence to under-save, by levying income tax and CGT on the normal 'risk-free' rate of return. As Adam \& Miller (2020) point out, a recurring wealth tax would make this problem worse. A wealth tax is insensitive to the actual rate of return so effectively (and broadly-speaking) taxes the normal rate of return but not the excess returns above that, thereby further distorting the decision whether to consume now or later. In this respect, a recurring wealth tax is antithetical to the objectives of the Mirrlees reforms to existing taxes on wealth.

In relation to inheritance tax, the objectives of the Mirrlees Review were to advance equality of opportunity and to seek redistribution at relatively low efficiency cost (Mirrlees et al., 2011, ch.15). ${ }^{55}$ Under a CIT approach, the aim would be to achieve horizontal equity across different forms of receipt, on the basis that the receipt of an inheritance or gift increases an individual's command over economic resources (and hence ability to pay) just like any other form of income. A wealth tax would not advance horizontal equity in this respect and so could not serve as an alternative to reforming the taxation of transfers of wealth under a CIT approach. However, it remains to examine whether a wealth tax could substitute the objectives of the Mirrlees Review in relation to reforms of IHT.

A wealth tax seems a poor substitute for IHT reform in terms of equality of opportunity, because unlike a tax on the transfer of wealth it does not discriminate based on source: a wealth tax falls equally on someone whose wealth results from their own effort and skill (e.g. the archetypal 'rags to riches' entrepreneur) as it does on someone whose wealth is entirely derived from inheritances. This is likely to be a key issue in determining the relative appeal of a wealth tax compared with a fully functioning tax on transfers of wealth (whether donor or donee based). At the same overall level of redistribution across the entire population, a wealth tax is less well-targeted at

\footnotetext{
55 This invocation of equality of opportunity represented an ad hoc departure from the optimal tax theory approach that underlay the other key recommendations of the Mirrlees Review. Furthermore, strict adherence to the aim of equality of opportunity would tend to imply a $100 \%$ inheritance tax (Haslett, 1986). 22
} 
redistributing 'undeserved' wealth than an inheritance or gift tax. For those who are motivated by process-based concerns about wealth inequality, this is an unappealing feature of a wealth tax.

From an outcome-based perspective, it is difficult to assess whether or not a wealth tax could redistribute more efficiently than a reformed IHT. Ultimately, this would depend not only on the design but also the rates and thresholds applied to each. It is important to note that under the current IHT, effective tax rates are not progressive at the top, due to the widespread use of tax reliefs (OTS, 2018). Consequently, a wealth tax may be able to do a better job of redistribution than the current IHT, especially amongst the very wealthy, unless it succumbs to the same political pressures that have rendered IHT ineffective. If it becomes clear that the necessary basebroadening reforms to IHT will not be politically possible, but that the introduction of a wealth tax might be, then this may present a case for seeking to replace IHT with a wealth tax. This issue is discussed further in Section 4.1 below. 


\section{Interactions with existing taxes}

The preceding section looked at options for reforming existing taxes on wealth and considered the implications for whether and under what conditions it may be a good idea to introduce a wealth tax. This section approaches from a different perspective. Suppose that the government has decided that it wants to introduce a wealth tax: how should it interact with existing taxes on wealth? I consider three subsidiary questions. First, would there be a case for abolishing any existing taxes if a wealth tax was introduced? Second, under what conditions (if any) should wealth tax payments be deductible against other taxes? And third, could a wealth tax be used as a backstop for existing taxes on wealth by specifically targeting individuals who pay relatively little as a proportion of their wealth under the current system?

\subsection{Abolition}

Any new taxes are inevitably challenging to introduce, both administratively and politically. Linking the introduction of a wealth tax to the abolition of one or more existing taxes could therefore be an appealing political device; it might also help to counterbalance some of the additional compliance costs imposed on individuals and HMRC. If a government were thinking along these lines, which tax (or taxes) would be the most appropriate to abolish in order to make way for a wealth tax? Here I consider two possible candidates: IHT and SDLT. Both of these taxes are extremely unpopular: in a 2015 YouGov poll they ranked as the two least 'fair' taxes in the entire tax system (Shakespeare, 2015); they are also amongst the most dysfunctional and arbitrary taxes in terms of their purpose and design. Prima facie, these factors make them appealing targets for replacement by a wealth tax.

As the Meade Report identified, a wealth tax has some affinity with IHT. As the authors put it, 'a tax on the transfer of inherited wealth as it passes down from parent to child is in effect a periodic charge, levied once a generation, on the holding of such wealth. In so far as this is the case it may be regarded ... like an annual wealth tax, but one which is levied once a generation instead of once a year' (Meade et al., 1978, p.317). The notion of IHT as a 'once-per-generation' wealth tax may now be out of date since there is also a good deal of generation-skipping (Bourquin, Joyce \& Sturrock, 2020). But even as a tax once per generation, IHT is extremely leaky, for the reasons outlined in Section 1 above: it grants reliefs over large parts of the tax base; many lifetime gifts are not covered; and the wealthiest also benefit from other tax planning opportunities. Moreover, the tax only raises around $£ 5$ billion per year (less than $1 \%$ of total tax revenues), although it must be noted that the vast majority of this (78\%) came from individuals with a net estate of over $£ 1$ million (HMRC, 2018).

A wealth tax could potentially have several political advantages over IHT. First, it appears to be much more popular with the public (Rowlingson, Sood \& Tu, 2020). Second and relatedly, if a wealth tax were designed as a recurring annual tax, people would know whether or not they were paying it and in what amount, whereas it appears that part of the unpopularity of IHT may stem from the fear that one may have to pay it (as a single lump sum) in future, whether or not this actually materialises. Third, the effectiveness of IHT is reliant on policy stability over the long-run: there is a risk that IHT could be abolished in future; by contrast a wealth tax could bring in revenue from the living wealthy now and is not reliant on the policy still being in force when they die.

Of the three OECD countries that currently operate a wealth tax, Spain and Switzerland also have taxes on inherited wealth, whereas Norway does not. France, which retained a wealth tax until 2018, simultaneously enforced (and still enforces) a lifetime receipts tax payable on gifts and bequests. However, this impression does not tell the whole story. In Switzerland the tax on inheritances and gifts only operates at cantonal level, and all but three cantons exempt transfers to spouses and children, so the tax has very little application in practice (Aebi \& Eckert, 2020). There is a similar picture in Spain, where the regions are entitled to set their own rates and 
deductions, and Madrid offers nearly a 100\% deduction for transfers to spouses and children. Norway abolished its tax on inheritances and gifts in 2014 citing concerns about liquidity for family businesses, whilst retaining its wealth tax.

The deficiencies of the existing IHT, coupled with the international experience of countries that already have a wealth tax, suggest a case for abolishing IHT altogether in exchange for introducing a wealth tax. This approach would raise some transitional issues, however. There would be a windfall for estates that escaped IHT but had not yet paid much wealth tax. Depending on the rates and thresholds of a wealth tax, it may be many years until an individual's accumulated wealth tax bill would reach the same level as the IHT that would have been due on their death. On the other hand, the wealth tax would also apply to the heirs of these estates, assuming that they were within the territorial scope of the tax (see further Chamberlain, 2020) and above the threshold. Consequently, from a Treasury perspective, there would be a re-timing of the tax receipts attributable to this wealth rather than a permanent loss of revenue. Nevertheless, this retiming could result in significant windfalls in individual cases, which may be regarded as unfair. To alleviate this problem, IHT could gradually be phased out rather than immediately abolished, either by reducing rates over several years or by maintaining IHT but allowing a relief for wealth tax paid by the deceased during their lifetime (although it should be acknowledged that such transitional provisions inevitably lead to some complexity).

Instead or additionally, a wealth tax could pave the way for abolition of stamp duty land tax. At present, the difficulty with abolishing SDLT from a public finance perspective is that it raises a lot of revenue. In 2018-19, residential SDLT raised £8.3 billion (HMRC, 2019a); however, revenues are very volatile and may be expected to fall sharply over coming years, as they did after the 2008 Financial Crisis. Liability is skewed towards the top, although less than for IHT: in 2018-19, 32\% of receipts were from purchases over $£ 1$ million. ${ }^{56}$ Another concern with abolishing SDLT is that it would simply result in a windfall gain to existing owners of residential property, because this saving would be reflected in an increase in house prices; however, this effect may be somewhat offset by the capitalisation effects of a wealth tax (Advani \& Tarrant, 2020). However, one drawback of replacing SDLT with a wealth tax is that the collection costs and tax gap would almost certainly be higher (Troup, Barnett \& Bullock, 2020).

\subsection{Deductions}

If a wealth tax was introduced, should it be deductible against other taxes due? In other words, when (if at all) should an individual who has paid the wealth tax be able to obtain a tax credit to reduce their tax liability under another tax? There are many specific issues that could be discussed here, and space precludes an individual treatment of them. Instead I set out below an underlying principle that can be applied in most cases. ${ }^{57}$

In short, the availability of deductions or reliefs (or to put the point the other way around: measures to avoid 'double taxation') must depend on whether a wealth tax serves the same purpose as another tax: to the extent that it does, there may be a case for allowing deductions if the purpose is already fully served by the other tax. However, if the taxes serve different purposes then there should be no objection to cumulating them (i.e. not allowing any relief), even if both taxes are assessed in respect of the same asset.

\footnotetext{
${ }^{56}$ This figure is based on gross property values, not total net wealth, but it seems reasonable to assume a strong correlation between these.

${ }^{57}$ There are some instances in which a deduction or relief is intended to reflect specific policy objectives (known as 'tax expenditures') where the considerations may be different. For example, there is a question of whether gift aid relief in respect of charitable donations (which currently applies for income tax) should be extended to a wealth tax.
} 
To see this, it may help to use some examples. To take an easy case first, no one thinks that income tax should be deductible against tobacco duty, even where an individual has bought cigarettes out of their taxed income. The reason is that these two taxes clearly serve different purposes. Second, this remains the case even where the taxes are due in respect of the thing (here: the cigarettes). Cigarette manufacturers are liable for both tobacco duty and VAT, again because they serve different purposes: VAT is a broad-based tax on consumption whereas tobacco duty is specifically aimed at reducing smoking.

Nevertheless, in the context of taxes on wealth in particular, the issue of 'double taxation' is often raised. For example, IHT is sometimes said to involve double taxation on the assumption that the assets in the estate will have been purchased out of taxed income or gains (Lee, 2007). More often, it is claimed that charging both IHT and CGT on death would amount to double taxation, and further that that this is a reason for retaining CGT forgiveness on death. ${ }^{58}$ Whether this charge of 'double taxation' is valid depends on whether IHT and CGT serve the same purpose or not. It does not depend on whether both taxes have been charged in respect of the same asset.

To determine whether a wealth tax should be deductible against other taxes, we therefore need to know its purpose, which takes us back to Section 3 above. If a wealth tax is justified to correct the past, or because wealth affects taxable capacity or welfare distinct from income or consumption, then the tax is serving a different purpose from any of the existing taxes on wealth and should be levied on top, with no reliefs. By contrast, if a wealth tax is justified only in place of reforming existing taxes on wealth, and so intended to serve the same purpose by another means, then to the extent that existing taxes serve the same purpose already, there may be some case for allowing reliefs.

However, even where reliefs may be justified in principle, it is doubtful whether they would be a good idea in practice, due to the additional legislative complexity that they would generate. There are almost no examples of wealth tax payments generating a relief or tax credit against other domestic taxes in any of the countries that operate a wealth tax. Prior to the abolition of its wealth tax, France allowed a deduction from the inheritance tax base if wealth tax was due but not yet paid at the date of death; however, this represents a very limited timing provision only. Within the UK, there is a limited deduction for CGT in certain circumstances where the donor died within seven years of making a lifetime gift, which is therefore included in their IHT estate. There is also some deduction against IHT for offshore income gains that are crystallised on death. A handful of other obscure reliefs operate between existing taxes on wealth but experience seems to be that they can operate in arbitrary ways: likely because their design does not reflect the principles of deductibility outlined above.

There would be a much stronger case for allowing foreign tax credit relief where an individual who is liable to the UK wealth tax found themselves also liable to another country's wealth tax in respect of the same asset. ${ }^{59}$ There is already a network of Double Tax Treaties that exist bilaterally between the countries that currently have a wealth tax, to deal with this type of issue. If a wealth tax was introduced in UK, then it would be sensible to negotiate equivalent DTTs with these countries. The existing network of treaties indicates that this ought to be possible in principle, although it would require considerable diplomatic and administrative effort.

\footnotetext{
${ }^{58}$ Both the Mirrlees Review and the OTS have appropriately debunked this idea (Mirrlees et al., 2011, ch.15; OTS, 2019).

59 This would be most likely to occur in relation to non-residents holding UK assets that were liable to the wealth tax on the basis of the situs of the asset (such as UK land), where they were also liable to a wealth tax on their worldwide assets in their country of residency.
} 


\subsection{Alternative minimum tax}

For some, the primary function of a wealth tax would be to raise revenue from those who have high wealth but who pay relatively little tax as a proportion of that wealth (or as a proportion of their comprehensive income, including accrued but not yet realised gains). One reason for this state of affairs could be if the individual had structured their remuneration in such a way as to reduce their effective tax rate on income and gains to a very low level, for example by making use of capital gains and dividends in place of taking a salary taxed as earnings. Another reason however, may be because the individual has relatively little taxable income or gains as a proportion of their wealth, either because they own mostly low-yielding assets or they are accumulating gains (for example by retaining profits in a company) that have not yet been realised.

One way of addressing these concerns could be to use a wealth tax as an 'alternative minimum tax' (AMT), effectively serving as a backstop for income tax and CGT. The US already operates an AMT, however it applies only to taxable income, effectively setting a floor on the tax that can be obtained by combining different income tax reliefs. In the UK, Advani \& Summers (2020b) have gone further, suggesting an AMT that combines both taxable income and gains, to prevent individuals from excessively reducing their effective tax rate by repackaging income as gains. An AMT based on wealth would be a yet further extension of this idea, targeted at those with high wealth but relatively little taxable income and gains.

In the simplest terms, all individuals within the territorial scope of the wealth-based AMT would be required to pay a minimum total amount in tax, calculated as a percentage of their wealth. If the individual already paid more than this amount in other taxes, then there would be no additional tax to pay. In effect, this is equivalent to giving relief against the wealth tax for a wide range of other taxes. Clearly, this would significantly reduce the revenue that the wealth tax would raise. However, in this form, the purpose of the wealth tax would be primarily as a backstop to protect the rest of the tax base, rather than as an independent tax. Those who already pay substantial sums in tax under the current system - for example, individuals without substantial wealth who receive most of their income from employment - would be entirely unaffected by a wealth-based AMT since their existing tax payments would easily exceed the minimum threshold.

A wealth-based AMT is potentially appealing in that it would recognise some role for wealth within the notion of ability to pay, without affecting the majority of individuals for whom income or consumption is likely to be a more appropriate measure. ${ }^{60}$ It could also serve as an antiavoidance (or anti-tax planning) device. However, such a tax may be politically challenging, as its effect would be to flip conventional concerns about the liquidity of 'asset-rich-cash-poor' taxpayers on their head (for evidence on this issue in UK public attitudes, see Rowlingson, Sood \& Tu, 2020). A wealth-based AMT would effectively target individuals who reported small (taxable) flows relative to their stock of wealth. This approach is the opposite of many countries with a wealth tax (including Spain and France), which operated a cap on wealth tax liability for taxpayers with low income (see further Loutzenhiser \& Mann, 2020). The public perception that individuals with low income have low taxable capacity, irrespective of their wealth, may be an insurmountable obstacle to public acceptability of a wealth-based AMT.

A wealth-based AMT would also face several administrative challenges. First, there would inevitably be calls to expand the range of tax payments that would count in assessing whether the minimum payment (as a percentage of wealth) had been met. Aside from income tax and CGT, the scope could potentially be extended to include (for example) the corporation tax or employer NICs paid by firms controlled by the individual, or SDLT, or IHT on lifetime gifts into trust. However, any such extensions would rapidly generate huge complexity in determining how to

60 This approach fits with Kay's observation that 'tax liabilities are based, not on-probably unobservabletaxable capacity, but on variables which we believe to be correlated with taxable capacity' (Kay, 2010, pp.662). 
allocate payments between individuals, their timing, and so on. Second, a wealth-based AMT would require assessment of a very large number of taxpayers since it would be difficult to determine ex ante who might be liable to the charge, despite that in most cases no tax would be due. Given the cost of valuations for both taxpayers and the revenue (see further Troup, Barnett \& Bullock, 2020), such an approach is unlikely to be administratively viable. 


\section{Conclusion}

The UK's existing taxes on wealth are a mess. There is more than one possible direction for reform: I have considered both the Mirrlees approach which reflects the idea of consumption as the ideal tax base, and an alternative approach based on the idea of (comprehensive) income as a tax base. However, it is important to emphasise that despite these different directions, there are nevertheless a long list of reforms to existing taxes on wealth that would be merited under either approach, or indeed any coherent approach. This reflects the fact that many features of the UK's current approach to taxing wealth cannot be defended on any rational basis. In this sense, the area is ripe for reform.

Against this backdrop, why introduce a wealth tax on top? I have suggested three possible reasons. First, most proposals to reform existing taxes on wealth are wholly prospective: they would correct the system going forward but would do nothing to correct the mistakes of the past. A wealth tax could potentially play this role. Second, a wealth tax might serve as an ongoing corrective to processes of excessive and/or unjustified wealth accumulation; however, it would be second-best compared with policies to address these processes directly. Third, there remains a debate about whether wealth provides distinctive benefits beyond the consumption that it funds. The Mirrlees Review sidestepped this debate but it requires re-attention; although more evidence is required, there are reasons to give the insights of the Meade Report a fresh airing in particular whether the benefits of wealth in providing security, independence, influence and power reflect additional taxable capacity over and above that indicated by an individual's income and/or consumption.

Could a wealth tax provide an alternative to reforming existing taxes on wealth? In relation to income tax and capital gains tax, the short answer is no. It may help to reduce the disparity in tax treatment between returns on wealth and work, but in other respects it would make things worse. If a wealth tax is implemented, long overdue reforms to income tax and CGT should still be done as well. The position in relation to IHT is more nuanced. A wealth tax cannot perform the same function as IHT in advancing equality of opportunity, because it applies to all wealth regardless of its source. However, if reforming IHT proves politically infeasible, a wealth tax could provide a progressive alternative. Council tax will require reform regardless of a wealth tax, although a wealth tax could contribute to a somewhat more progressive system for the taxation of main homes.

In any case, it may be wise not to look too narrowly for the range of 'alternatives' to a wealth tax. In the face of unprecedented pressures on public finances, a government may consider that its objective is crudely just to 'raise revenue'. In this context, the issue would be not just whether a wealth tax would be preferable to reforming existing taxes on wealth, but whether it would be preferable to a raft of other likely ways in which the government may seek to increase tax revenues. Based on past experience, the most likely may be a rise in the headline rates of one of the 'Big 3' taxes: the basic rate of income tax, NICs or VAT. Another possibility, which was tried after the Financial Crisis (from 2010-2013), could be to increase the top rates of income tax. I have not attempted to compare the distributional impacts and efficiency costs of these options in this paper, but that is an important agenda for further analysis.

In this paper I have tried to steer clear (as far as possible) of excessive speculation regarding the political dimensions of reforming the taxation of wealth. ${ }^{61}$ Nevertheless, two important notes of caution arise from such considerations. First, my analysis has proceeded on the charitable presumption that a wealth tax could escape anomalies and special pleadings that have dogged our existing taxes on wealth. But there is obviously a substantial risk that in practice, the actual

${ }^{61}$ For rigorous discussions of these issues in the context of a wealth tax, see Clarke et al., 2020; Perret, 2020; and Pope \& Tetlow, 2020. 
implementation of a wealth tax would diverge significantly from this ideal, in effect replicating or even exacerbating many of the unprincipled anomalies in our current system. Second, if there is limited political and administrative 'bandwidth' for major tax reform, then in practice a wealth tax 'in addition' to other reforms may be unrealistic, in which case policymakers must assess priorities. I have not dealt with these matters here because they are downstream of the inprinciple case for and against a wealth tax, which should be established first.

The call to reform existing taxes on wealth instead of introducing a wealth tax resonates with the most force when it is accompanied by a specific list of proposals and a firm commitment to enact them. Without these, the objection rings hollow. As the contributors to the Mirrlees Review rightly put it, 'an argument that a better policy is available should only be used as an argument against a particular policy proposal if the available alternative is actively pursued' (Banks \& Diamond, 2010, pp.561). Detractors from a wealth tax would do well to heed this injunction. 


\section{References}

Adam, S., and Miller, H. (2019). Principles and practice of taxing small business. (IFS Working Paper W19/31) London: Institute for Fiscal Studies.

Adam, S., and Miller, H. (2020). The Economics of a Wealth Tax. Wealth Tax Commission Evidence Paper, 3.

Adam, S., Emmerson, C., and Roantree, B. (2013). Broad shoulders and tight belts: options for taxing the better-off. In: C. Emmerson, P. Johnson and H. Miller, eds. 2013. The IFS Green Budget: February 2013. London: Institute for Fiscal Studies. Ch.9.

Advani, A., and Summers, A. (2020a). Capital Gains and UK Inequality. (CAGE Working Paper No. 465) Warwick: CAGE Research Centre.

Advani, A. and Summers, A. (2020b). How much tax do the rich really pay? New evidence from tax microdata in the UK. (CAGE Policy Briefing no. 27) Warwick: CAGE Research Centre.

Advani, A., and Tarrant, H. (2020). Behavioural responses to a wealth tax. Wealth Tax Commission Evidence Paper, 5.

Aebi, L., and Eckert, J. (2020). Switzerland. Wealth Tax Commission Background Paper, 133.

All-Party Parliamentary Group for Inheritance \& Intergenerational Fairness (2020). Reform of inheritance tax. London: Society of Trust and Estate Practitioners (STEP).

Auerbach, A. (2019). Tax Equivalences and Their Implications. NBER/Tax Policy and the Economy, 33(1), pp.81-107.

Banks, J., and Diamond, P. (2010). The Base for Direct Taxation. In: J. Mirrlees, S. Adam, T. Besley, R. Blundell, S. Bond, R. Chote, M. Gammie, P. Johnson, G. Myles and J. Poterba, eds. 2010. Mirrlees Review, Volume 1: Dimensions of Tax Design. Oxford: Oxford University Press. Ch.6.

Besley, T., Meads, N., and Surico, P. (2014). The incidence of transaction taxes: Evidence from a stamp duty holiday. Journal of Public Economics, 119, pp.61-70.

Bird-Pollan, J. (2017). The Philosophical Foundations of Wealth Transfer Taxation. In: M. Bhandari, ed. 2017. Philosophical Foundations of Tax Law. 1st ed. Oxford: Oxford University Press. Ch.9.

Boadway, R., Chamberlain, E., and Emmerson, C. (2010). Taxation of Wealth and Wealth Transfers. In: J. Mirrlees, S. Adam, T. Besley, R. Blundell, S. Bond, R. Chote, M. Gammie, P. Johnson, G. Myles and J. Poterba, eds. 2010. Mirrlees Review, Volume 1: Dimensions of Tax Design. Oxford: Oxford University Press. Ch.8.

Bourquin, P., Joyce, R., and Sturrock, D. (2020). Inheritances and inequality within generations. (IFS Report R173) London: Institute for Fiscal Studies.

Bourquin, P. and Waters, T. (2019). The effect of taxes and benefits on UK inequality. (IFS Briefing Note BN249) London: Institute for Fiscal Studies.

Chamberlain, E. (2020). Defining the tax base - Design Issues. Wealth Tax Commission Evidence Paper, 8. 
Chick, M. (2020). Taxing Wealth: A Historical Perspective. Wealth Tax Commission Background Paper, 121.

Clark, E., Gronwald, V., Guerrero-Fernandez, R. and Ramirez-Casillas, E. (2020). The Political Economy of the Abolition of Wealth Taxes in the OECD Wealth Tax Commission Background Paper, 123.

Corlett, A. (2018). Passing on: Options for reforming inheritance taxation. (Intergenerational Commission Report) London: Resolution Foundation.

Corlett, A., and Gardiner, L. (2018). Home affairs: Options for reforming property taxation. (Intergenerational Commission Report) London: Resolution Foundation.

Davis, A., Hecht, K., Burchardt, T., Gough, I., Hirsch, D., Rowlingson, K., and Summers, K. (2020). Living on Different Incomes in London: Can public consensus identify a 'riches line'? (Report) London: Trust for London.

Dolphin, T. (2010). Death and Taxes: Why Inheritance Tax should be replaced with a Capital Receipts Tax. (Briefing) London: Institute for Public Policy Research.

Eiser, D. (2020). Wealth Taxes and Devolution. Wealth Tax Commission Background Paper, 120.

Fuest, C., Peichl, A., and Siegloch, S. (2018). Do Higher Corporate Taxes Reduce Wages? Micro Evidence from Germany. American Economic Review, 108, pp.393-418.

Goodhart, W. (1988). Too good to be true? A proposal for the reform of taxes on gifts and inheritances. British Tax Review, (12), pp.473-481.

Haslett, D.W. (1986). Is Inheritance Justified? Philosophy \& Public Affairs, 15(2), pp.122-155.

Hilber, C.A.L., and Lyytikäinen, T. (2017). Transfer taxes and household mobility: Distortion on the housing or labor market? Journal of Urban Economics, 101, pp.57-73.

Hills, J., Bastagli, F., Cowell, F., Glennerster, H., Karagiannaki, E., and McKnight, A. (2013). Wealth in the UK: Distribution, Accumulation, and Policy. 1st ed. Oxford: Oxford University Press.

HMRC (2018). Inheritance Tax Statistics 2017-18. Published 30 July 2020.

HMRC (2019a). Annual Stamp Taxes Statistics 2018-19. Published 1 October 2019.

HMRC (2019b). Annual Tax on Enveloped Dwellings (ATED) 2018-19. Published 31 March 2020.

Kay, J. (2010). Commentary by John Kay. In: J. Mirrlees, S. Adam, T. Besley, R. Blundell, S. Bond, R. Chote, M. Gammie, P. Johnson, G. Myles and J. Poterba, eds. 2010. Mirrlees Review, Volume 1: Dimensions of Tax Design. Oxford: Oxford University Press. Ch.6.

Kopczuk, W. (2007). Bequest and tax planning: Evidence from estate tax returns. The Quarterly Journal of Economics, 122(4), pp.1801-1854.

Kopczuk, W. (2013). Incentive effects of inheritances and optimal estate taxation. American Economics Review, 103(3), pp.472-77.

Lee, N. (2007). Inheritance tax - an equitable tax no longer: time for abolition? Legal Studies, 27(4), pp. 678-708. 
Loutzenhiser, G., and Mann, E. (2020). Liquidity issues: solutions for the asset rich, cash poor. Wealth Tax Commission Evidence Paper, 10.

Meade, J., Ironside, D., Avery Jones, J., Bell, L., Flemming, J., Kay, J.A., King, M., Macdonald, M., Sandford, C., Whittington, G., and Willis, J. (1978). The Structure and Reform of Direct Taxation. London: George Allen \& Unwin.

Miller, H., Pope, T., and Smith, K. (2019). Intertemporal income shifting and the taxation of ownermanaged businesses. (IFS Working Paper W19/25) London: Institute for Fiscal Studies.

Mirrlees, J., Adam, S., Besley, T., Blundell, R., Bond, S., Chote, R., Gammie, M., Johnson, P., Myles, G., and Poterba, J.M., eds. (2011). Mirrlees Review, Volume 2: Tax by Design. Oxford: Oxford University Press.

Nanda, S., and Parkes, H. (2019). Just tax: Reforming the taxation of income from wealth and work. London: Institute for Public Policy Research.

Nozick, R. (1974). Anarchy, State \& Utopia. New York: Basic Books.

O'Donovan, N. (2020). One-off Wealth Taxes: Theory and Evidence. Wealth Tax Commission Evidence Paper, 7.

Office of Tax Simplification (2018). Inheritance Tax Review - first report: Overview of the tax and dealing with administration. London: Office of Tax Simplification.

Office of Tax Simplification (2019). Inheritance Tax Review - second report: Simplifying the design of Inheritance Tax. London: Office of Tax Simplification.

Office of Tax Simplification (2020). Capital Gains Tax Simplification Review: Scoping Document. London: Office of Tax Simplification. Published July 2020.

Perrett, S. (2020). Why did other wealth taxes fail and is this time different? Wealth Tax Commission Evidence Paper, 6.

Pope, T., and Tetlow, G. (2020). Delivering a Wealth Tax: The Role of Government. Wealth Tax Commission Evidence Paper, 12.

Robinson, B. (1989). Reforming the Taxation of Capital Gains, Gifts and Inheritances. Fiscal Studies, 10(1), pp.32-40.

Rowlingson, K., Sood, A., and Tu, T. (2020). Public Attitudes to a Wealth Tax. Wealth Tax Commission Evidence Paper, 2.

Sandford, C. (1987). Death Duties: Taxing Estates or Inheritances. Fiscal Studies, 8(4), pp.15-23.

Saez, E., and Zucman, G. (2019). The Triumph of Injustice: How the Rich Dodge Taxes and How to Make Them Pay. New York: WW Norton \& Company.

Scanlon, T. (2018). Why Does Inequality Matter?Oxford: Oxford University Press.

Shakespeare, S. (2015). Voters in all parties think inheritance tax unfair. (YouGov Poll) [online] Available at: <https://yougov.co.uk/topics/politics/articles-reports/2015/03/19/inheritancetax-most-unfair > [Accessed 2 September 2020].

Smith, A. (1776). The Wealth of Nations. London: Strahan \& Cadell 
Summers, A. (2019). Taxation of Wealth. In: J. Bradshaw, ed. 2019. Let's Talk about Tax. London: CPAG Press. pp.115-161.

Tiley, J. (2007). Death and Taxes. British Tax Review, (3), pp.300-319.

Troup, E., Barnett, J., and Bullock, K. (2020). The Administration of a Wealth Tax. Wealth Tax Commission Evidence Paper, 11. 


\section{Appendix A: Historical comparison of rates for indexing nominal returns on wealth}

FIGURE 1A: NORMAL RATE OF RETURN AND INFLATION RATE 1970-2020

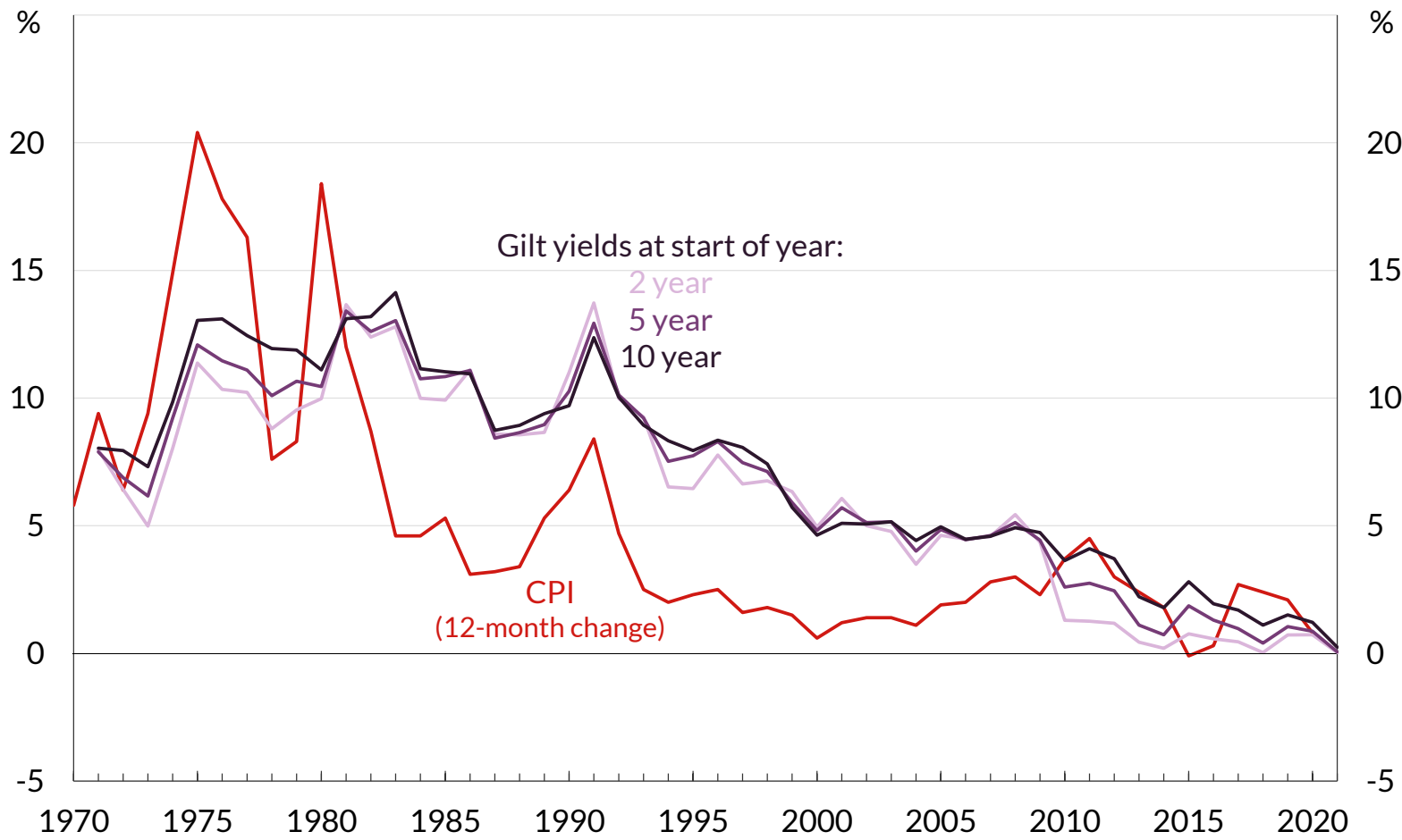

FIgURE 1B: DifFERENCE BETWEEN NORMAL RATE OF RETURN AND INFLATION RATE 1970-2020

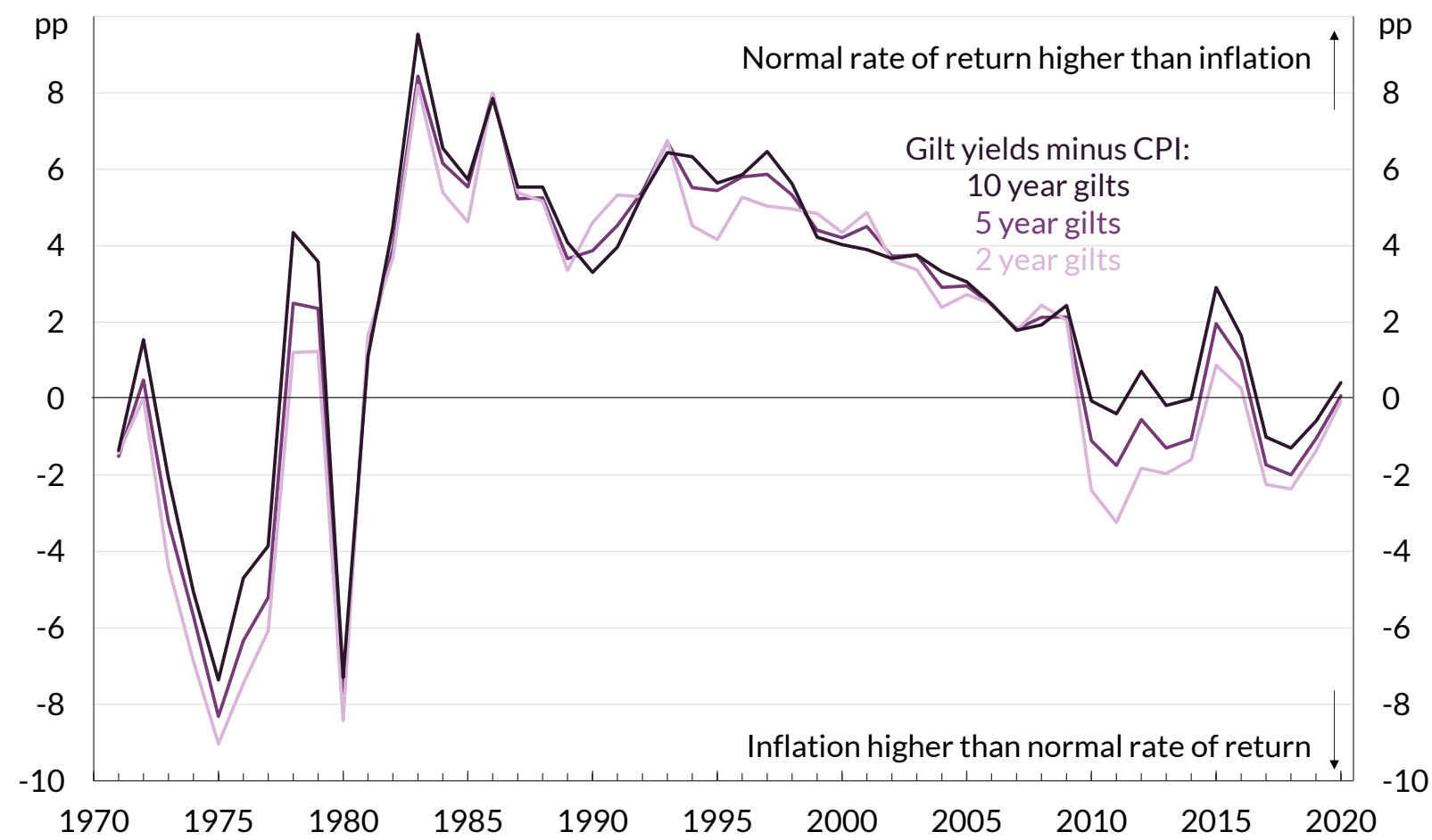

Notes: The date axis in both figures refers to the end of the tax year e.g. 2020 is the tax year 2019-20. Inflation is measured by growth in the Consumer Prices Index (CPI) over the 12 months to the end of the tax year. From 1989 onwards this is based on the ONS official index; for earlier years it is based on a modelled ONS historical CPI estimate. The normal rate of return (NRR) is measured by the interest rate on medium-maturity government bonds available at the start of the tax year, following Mirrlees et al. (2011, ch13).

Sources: Author's calculations using ONS and Bank of England data 
Figure 2A: MediuM-MATURITY GILT YieLdS AND THE BASE RATE 1970-2020

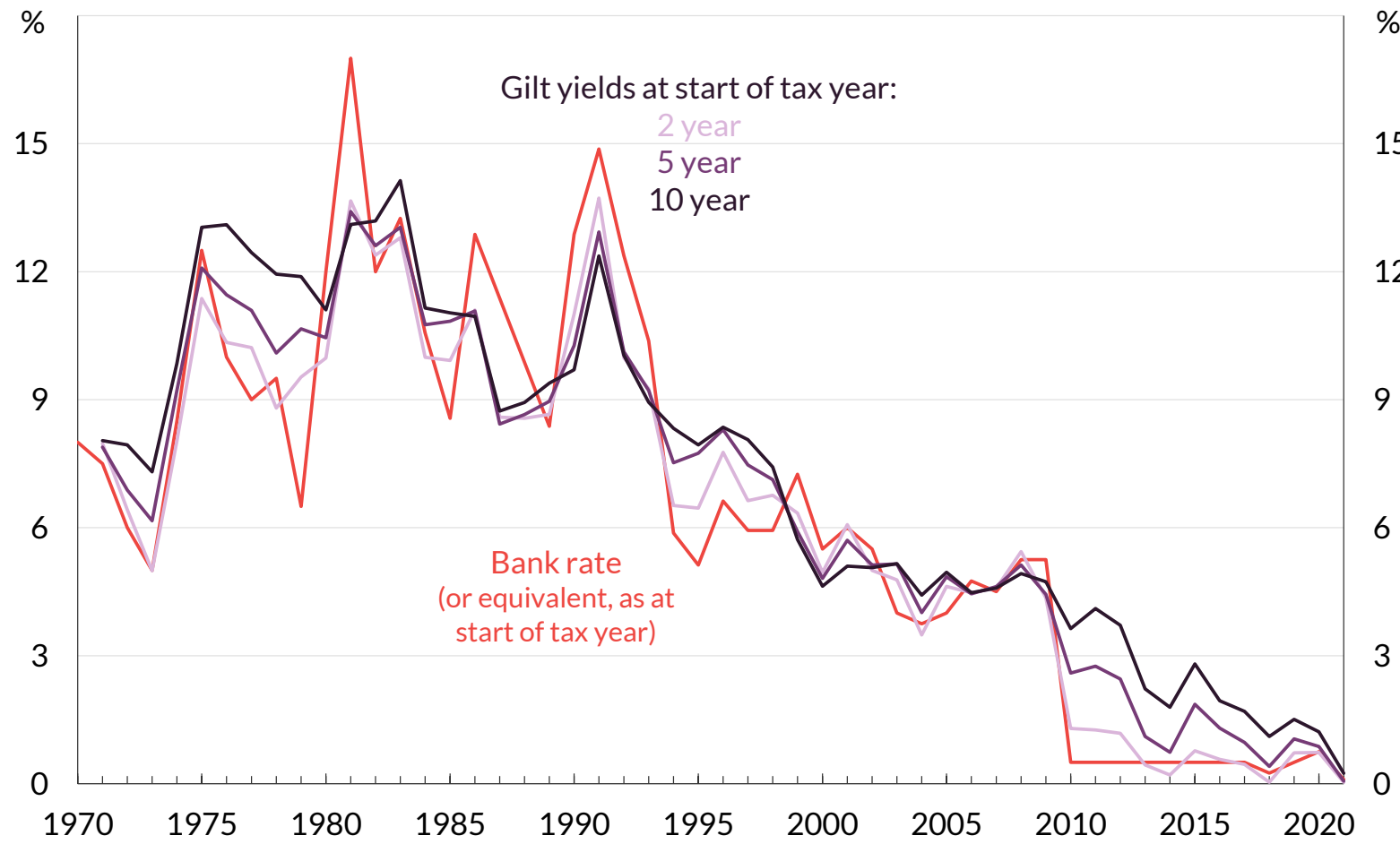

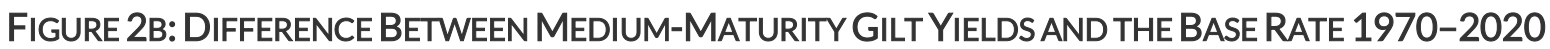

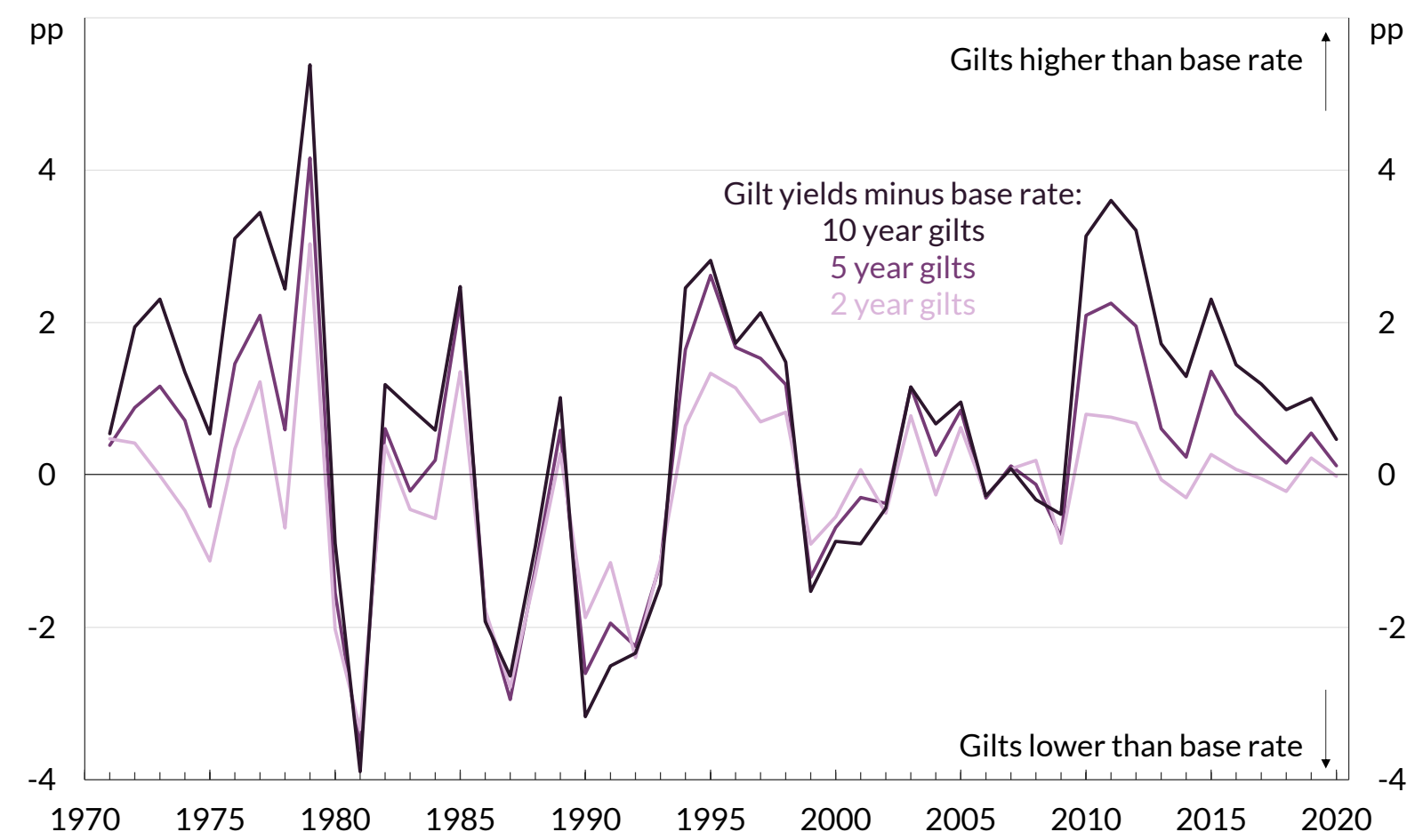

Notes: The date axis in both figures refers to the end of the tax year e.g. 2020 is the tax year 2019-20. The 'base rate' refers to the Bank of England Bank Rate and its predecessor equivalents, at the start of the tax year. 'Medium-maturity gilt yields' refers to the interest rate on $2 \mathrm{yr}, 5 \mathrm{yr}$ and $10 \mathrm{yr}$ government bonds available at the start of the tax year. In general, medium-maturity gilt yields have tended to lag changes in the base rate.

Sources: Author's calculations using Bank of England data. 


$\begin{array}{cccc}\text { TABLE 1A: COMPARISON OF INDICES FOR } & \text { 20-YEAR INVESTMENT TO APRIL } 2020(2000=100) \\ \text { Year } & \text { CPI index } & \text { NRR index } & \text { Base Rate index } \\ 2000 & 100.0 & 100.0 & 100.0 \\ 2001 & 101.2 & 105.1 & 106.0 \\ 2002 & 102.6 & 110.4 & 111.8 \\ 2003 & 104.1 & 116.1 & 116.3 \\ 2004 & 105.2 & 121.2 & 120.7 \\ 2005 & 107.2 & 127.3 & 125.5 \\ 2006 & 109.3 & 132.9 & 131.5 \\ 2007 & 112.4 & 139.0 & 137.4 \\ 2008 & 115.8 & 145.9 & 144.6 \\ 2009 & 118.4 & 152.8 & 152.2 \\ 2010 & 122.8 & 158.4 & 152.9 \\ 2011 & 128.3 & 164.9 & 153.7 \\ 2012 & 132.2 & 171.0 & 154.5 \\ 2013 & 135.4 & 174.8 & 155.2 \\ 2014 & 137.8 & 177.9 & 156.0 \\ 2015 & 137.7 & 182.9 & 156.8 \\ 2016 & 138.1 & 186.5 & 157.6 \\ 2017 & 141.8 & 189.6 & 158.4 \\ 2018 & 145.2 & 191.7 & 158.8 \\ 2019 & 148.3 & 194.6 & 159.6 \\ 2020 & 149.4 & 197.0 & 160.8\end{array}$

TABLE 1B: COMPARISON OF INDICES FOR 10-YEAR INVESTMENT TO APRIL 2020 (2010=100)

$\begin{array}{llll}\text { Year } & \text { CPI index } & \text { NRR index } & \text { Base Rate index } \\ 2010 & 100.0 & 100.0 & 100.0 \\ 2011 & 104.5 & 104.1 & 100.5 \\ 2012 & 107.6 & 108.0 & 101.0 \\ 2013 & 110.2 & 110.4 & 101.5 \\ 2014 & 112.2 & 112.3 & 102.0 \\ 2015 & 112.1 & 115.5 & 102.5 \\ 2016 & 112.4 & 117.7 & 103.0 \\ 2017 & 115.5 & 119.7 & 103.6 \\ 2018 & 118.2 & 121.1 & 103.8 \\ 2019 & 120.7 & 122.9 & 104.3 \\ 2020 & 121.7 & 124.4 & 105.1\end{array}$

TABLE 1C: COMPARISON OF INDICES FOR 5-YEAR INVESTMENT TO APRIL 2020 (2015=100)

$\begin{array}{llll}\text { Year } & \text { CPI index } & \text { NRR index } & \text { Base Rate index } \\ 2015 & 100.0 & 100.0 & 100.0 \\ 2016 & 100.3 & 101.9 & 100.5 \\ 2017 & 103.0 & 103.7 & 101.0 \\ 2018 & 105.5 & 104.8 & 101.3 \\ 2019 & 107.7 & 106.4 & 101.8 \\ 2020 & 108.6 & 107.7 & 102.5\end{array}$

Notes: 'Year' refers to the end of the tax year e.g. 2020 is the tax year 2019-20. 'CPI index' is based on the Consumer Price Index. 'NRR index' is based on 10yr gilt yields. 'Base Rate index' is based on the Bank of England Bank Rate. The $\mathrm{CPI}$ index reflects the inflation rate at the end of the tax year; the NRR and Base Rate indices reflect the rates at the start of the tax year.

Sources: Author's calculations using ONS and Bank of England data. 


\section{Appendix B: Example}

Fred owns and works in a company worth $£ 5$ million, which he purchased ten years ago for $£ 1$ million. He does not pay himself any salary or dividends. He lives in a 11 million apartment in Westminster, which he owns outright. He also owns 13 million worth of additional properties, from which he receives rent of $£ 150,000$ per annum. At the start of the 2020-21 tax year, Fred sells his shares in the company and gives all of the proceeds to his son.

Under the current tax system, Fred would pay total tax of approximately $£ 0.9$ million. This includes CGT of approximately $£ 0.8$ million on the sale of his company at a rate of $20 \%$ on a chargeable gain of $£ 4$ million (equal to his nominal gain). If the company was owned equally between Fred and his spouse and the qualifying conditions were satisfied, then business assets disposal relief would reduce the CGT by a further $£ 200,000$ (on up to $£ 2$ million of qualifying gains between them). Fred would also pay income tax of approximately $£ 60,000$ on his rental income, and council tax of approximately $£ 1,500$ on his apartment. There would be no tax to pay in respect of the gift to Fred's son, provided that Fred did not reserve any benefit in the gift and survived for seven years.

Under the Mirrlees Review approach, Fred would pay total tax of approximately $£ 1.3$ million. ${ }^{62}$ This includes CGT of approximately $£ 1.2$ million on the sale of his company, based on a chargeable gain of $£ 2.76$ million, calculated as the nominal gain ( $£ 4$ million) minus a rate of return allowance equal to the base cost of his investment ( $£ 1$ million) multiplied by the compound normal rate of return since $2010(=1.244) .{ }^{63}$ The CGT rate of $42.5 \%$ is calculated as the combined rates of income tax and NICs minus corporation tax. Under 'pure' Mirrlees, ${ }^{64}$ Fred would pay approximately $£ 8,000$ in housing services tax on his apartment, equivalent to $20 \%$ VAT on a rental value of $£ 40,000$ (assuming a rental yield of $4 \%$ ), plus approximately $£ 20,000$ income tax (including NICs) on this imputed rent. He would also pay approximately $£ 80,000$ income tax (including NICs) on the rental income from his additional properties. ${ }^{65}$ Fred's son would pay the lifetime receipts tax on the value of the gift received.

Under a comprehensive income tax approach, Fred would also pay total tax of approximately $£ 1.3$ million. This includes CGT of approximately $£ 1.2$ million on the sale of his company, based on a chargeable gain of $£ 2.78$ million, calculated as the nominal gain ( $£ 4$ million) minus an inflation allowance equal to the base cost of his investment ( $£ 1$ million) multiplied by the compound inflation rate since $2010(=1.217) .66$ The CGT rate of $42.5 \%$ is again calculated as the combined rates of income tax and NICs minus corporation tax. Fred would pay approximately $£ 20,000$ income tax (including NICs) on his apartment, based on an imputed rent of $£ 40,000$ (assuming a rental yield of $4 \%$ ), plus approximately $£ 80,000$ income tax (including NICs) on the rental income from his additional properties. ${ }^{67}$ Fred's son would pay income tax on the value of the gift received (aggregated with his other income for the tax year), although likely subject to averaging provisions to smooth the income over multiple years.

\footnotetext{
62 These calculations (and similarly for the comprehensive income tax below) are on a static basis in that they do not take account of changes in asset prices and yields that may result from changes in tax treatment. ${ }^{63}$ For details of the indexation applied, see Appendix A, Table $1 \mathrm{~b}$.

${ }^{64}$ This reflects the principled approach prescribed by the Mirrlees Review, without any reduction in housing services tax rate and including tax on imputed rent (Mirrlees et al., 2010, ch.16).

${ }^{65}$ This imputed and actual rental income would be subject to the rate of return allowance (RRA), but since the normal rate of return was close to zero at the start of the 2020-21 tax year, the RRA would be approximately nil.

${ }^{66}$ For details of the indexation applied, see Appendix A, Table $1 \mathrm{~b}$.

${ }^{67}$ This imputed and actual rental income would be subject to an inflation allowance, but since the inflation rate is likely to be close to zero at the end of the 2020-21 tax year, this allowance will be approximately nil. 38
} 